Article

\title{
Sustainability Attributes in Real Estate Development: Private Perspectives on Advancing Energy Regulation in a Liberalized Market
}

\author{
Felipe Encinas ${ }^{1,2, *}\left(\mathbb{D}\right.$, Carlos Aguirre $^{3}$ (D) and Carlos Marmolejo-Duarte ${ }^{4}$ \\ 1 Escuela de Arquitectura, Facultad de Arquitectura, Diseño y Estudios Urbanos, \\ Pontificia Universidad Católica de Chile, Providencia, 7520245 Santiago, Chile \\ 2 Centro de Desarrollo Urbano Sustentable (CEDEUS), Providencia, 7520246 Santiago, Chile \\ 3 Escuela de Construcción, Facultad de Arquitectura, Diseño y Construcción, Universidad de las Américas, \\ Sede Providencia, Providencia, 7500975 Santiago, Chile; caguirre@udla.cl \\ 4 Escola Tècnica Superior d'Arquitectura de Barcelona, Centre de Política de Sòl i Valoracions, \\ Universitat Politècnica de Catalunya, 08028 Barcelona, Spain; carlos.marmolejo@upc.edu \\ * Correspondence: felipe.encinas@uc.cl; Tel.: +56-2-2354-7721
}

Received: 28 November 2017; Accepted: 30 December 2017; Published: 9 January 2018

\begin{abstract}
In real estate markets where energy efficiency certificates are not mandatory, such as Santiago in Chile, incorporating solutions that respond to the growing demand for sustainability entails a natural tension between their acceptance as necessary measures and the way they are addressed by the market. Under this mechanism, sustainability attributes have been introduced that are communicated individually through real estate promotion. A methodology consisting of two approaches was utilized to investigate the cross-validation of attributes, in terms of supply and demand, and the evolution of them in 8255 real estate advertisements for the period 2012-2017. Their positioning was more evident in higher-value homes, where they were identified as consolidated attributes, while they are considered innovations at the lower end of the market. However, as evidence suggests, sustainability attributes decline in relative importance over time, ceasing to be considered marks of distinction. This suggests that this model should be reviewed from a public policy perspective, with the understanding that the current voluntary standards must compete with other attributes. At the same time, it is necessary to make progress in the improvement of the obligatory minimum standards with the objective of establishing a more demanding baseline that incentivizes competitiveness in the market.
\end{abstract}

Keywords: sustainable construction; real estate market; sustainability attributes; energy regulation; energy performance certification

\section{Introduction}

\subsection{Real Estate Attributes as a Value-Added Strategy}

While attempts have been made to evaluate the impact of architectural design on real estate prices through the use of econometric models-in association with studies that have won awards from trade associations, surveys among architects or the definition of formal and constructive characteristics of neighborhoods and housing [1-3] —interest in the quantitative identification of the benefits to be obtained in connection with community life, comfort and sustainability in its broadest sense, is more recent [4-6]. However, if one takes as an approximation of architectural design some of the characteristics that determine the habitability and durability of housing such as energy efficiency measures or minimum dimensions of a dwelling, a perception of such characteristics as representing alternatives that entail additional costs may take hold, which may reduce the immediate profitability of 
the real estate product [7]. However, it could also be assumed that these characteristics have a positive effect on willingness to pay; thus, higher prices for housing allow compensating for the additional production costs, thus encouraging the development of such elements by real estate developers.

In short, the question of how architectural design can capture value in a market context represents a topic of great interest. From a real estate perspective, a specific key to determine the origin of this relationship can be identified in the importance given to the relationship between the value of land and the projects that are situated on it. For example, in feasibility studies, developers begin with the price of land and calculate the profit that can be obtained from a project once the design, construction and characteristics associated with a place are determined as a result of said initial price. In other words, the discussion involves the relationship between the traditional model of urban rents earned by real estate developers versus consumers who define their decision to purchase based on housing price (associated with the mortgage loan to be obtained). Based on this logic, it can be inferred that this profit model could minimize the attributes of architectural design to balance a potential consumer's decision to purchase in a highly competitive scenario.

At this point, it is necessary to note that the decision to purchase a real estate product is associated with the assessment of its constituent attributes. According to Lancaster's definition, housing — considered a complex good—is not sought for itself, per se, but for the attributes contained in each product [8]. In this sense, Rosen proposed a general model for the supply and demand of heterogeneous goods, according to which it is recognized that most products are composed of a set of clearly differentiated attributes that satisfy different needs and tastes [9]. Consequently, it is assumed that the most important attributes will have a greater impact on determining preferences and choices by virtue of compensatory logic or trade-offs [10]. It is in this sense that architectural design could be interpreted as another attribute, and as a result, displaced by others that are a priori more relevant for the market niche at which it is aimed, such as locational attributes for middle-income segments [11]. However, in high-income sectors, architecture could constitute an important attribute for the signification and profiling of the type of user one seeks to attract, as observed in [12], where the choice of a referent of national architecture constituted the strategy of value construction for an exclusive high-income condominium.

However, in the context of sustainable construction, this mechanism is made difficult by what David Cadman defined as "the vicious cycle of blame" [13]. According to this mechanism, the different actors intervening in the real estate market are willing to undertake an action but claim that they rely on other actors to perform a prior action-where the former and latter are concatenated-generating a spiral of inaction. In this way, consumers may demand more energy efficient homes but give up because there are very few available. Architects may effectively design such houses; however, developers do not request them. Developers may be interested in these more sustainable buildings; however, they doubt that investors will finance them. Further, investors may be willing to finance such projects; however, they find that there is no demand for them. In this context, one way in which this vicious cycle can be broken is by reducing the information asymmetry-a known market failure-through the adequate communication of sustainability in real estate projects [14].

Consequently, it is possible to propose a hypothesis that observes and values sustainability attributes on the basis of their contribution to the definition of the real estate product. This observation is contextual; and, therefore, it jointly evaluates the attributes of an existing and known sale, with the advertising emphasis established by each seller. In addition, it should be recalled that the space in which these projects are located is constructed by social and urban factors, which are necessary to establish upon identifying specific contexts [15]. However, it is asserted that decisions to buy and sell homes are based on financial ability, and therefore, they inherit both the social practices of agents (translated into their tastes and the financial means they possess at the time of making a decision to buy or sell) as well as the context or state of the housing supply at that moment, generating a conditional relationship between both developers and consumers [16]. In this way, the definitions of attributes, revealed by both real estate promotion and demand, are intimately related. 
This article first seeks to describe the way in which real estate market assumes and communicates sustainability attributes in a liberalized context. Further, the aim is to evaluate whether the mechanism of attributes proposed by the residential real estate market is capable of building a permanent proposal for the construction of value and whether it represents an alternative for incentivizing the incorporation of sustainability in construction. For that purpose, a methodology consisting of both cross-sectional and longitudinal analyses was proposed to investigate sustainability attributes in Santiago. As the capital city of the country, it has a great importance, since it concentrates-at the same time-the $45 \%$ of the population [17] and $57 \%$ of the housing supply from the national real estate market [18]. These approaches were applied to study the cross-validation of attributes in terms of supply and demand for two housing microsectors, and the evolution of them through the real estate advertising. While it has been recognized that the market is able to position some energy efficiency attributes in the supply through the individual communication of these attributes in real estate promotion, there is a number of gaps that limit the introduction of sustainable construction as a competitive advantage. The phenomenon of greenwashing-understood as misinformation disseminated by a company to present a public image of environmental responsibility—certainly represents a threat when the sustainability of a project (and therefore, its development) is based solely on individual attributes without validated information [14]. In this sense, value is placed-from a market perspective—on the possibility of advancing in the strengthening of the national building code in terms of its requirements for energy performance and mandatory energy certification.

In addition to this, in a real estate market such as this, where there is no strict regulation on the constructive elements with respect to energy performance, the econometric models that had initially been tested were not conclusive and could not be replicated given the difficult access to actual transaction prices. Indeed, it was not possible to access data directly, since they should be collected from the property registry with an approximate phase-out of 18 months, from placing an offer for the property, its promotion and the purchase decision from the demand side. Due to these considerations, the presented study should be considered as exploratory in nature.

\subsection{The Promotion of Energy Efficiency Housing in Chile}

In most countries, energy efficiency at the residential level has been largely delegated to the dynamics of real-estate markets after setting a minimum level. This regulatory definition, which can be viewed from a prescriptive perspective [19] (in relation to demands due to the building element, for example, in terms of the thermal transmittance of walls or ceilings [20]) or from a performance perspective [21-23] (associated with performance indicators, such as heating demand or consumption), is in certain cases supplemented by the mandatory inclusion of energy certificates, which typically takes the form of ranking by categories, giving rise to labelling [24].

In this context, Chile's housing market can be characterized by a weak government presence-defined by López-Morales, Gasic and Meza as "urban state-entrepreneurialism" [25], which implies "not only that the State operates actively in the production of favorable market conditions but also that the market operates within the State with its logics of competition and dialectic of volatility versus spatial anchoring of capital" [26] (p. 83). While the new national urban policy [27] has presented elements of city management, in its analysis it is observed that the real estate market is very poorly regulated because the externalities of new developments are passed on to the compensation of developers with very few regulations. According to this logic, the liberalization of the Chilean markets, especially the real estate markets, has made the state reactive in the establishment of solutions to existing problems. Despite this, Chile was one of the first countries in the region to adopt mandatory energy regulation for housing. Indeed, the so-called "thermal regulation" in the year 2000 established requirements for the maximum permissible thermal transmittance for roofing, while the 2007 update added thermal conditioning requirements for roofing, perimeter walls and ventilated floors [28] throughout the national territory. Similarly, Argentina, the other country in the region that (along with Chile) has established energy requirements in certain climate zones (primarily related to heating) and 
implemented mandatory requirements for the Province of Buenos Aires in 2003, the city of Rosario in 2010 and the city of Buenos Aires in 2012 [29]. In addition, Brazil recently incorporated a mandatory energy regulation at the residential level in 2013 [30,31].

However, this regulation, whose standards have been assessed as an initial definition, but are admittedly lacking in terms of their effective contribution to the energy efficiency of homes [32-34], has not been updated in 10 years. In addition, these standards refer exclusively to performance in winter-which is not addressed from a performance-based perspective-and does not include any criteria for summer. The OECD itself has observed the issue, strongly recommending that the country could make progress on better thermal standards to "improve housing quality and protect public health" [35] (p. 23). As a result, the Ministry of Housing and Urban Planning promoted a proposal to update national thermal regulations in 2014 [36], which contained standards that represented a considerable improvement over the previous situation. Such standards ranged from a value of $1.9 \mathrm{~W} / \mathrm{m}^{2} \mathrm{~K}$ to $0.6 \mathrm{~W} / \mathrm{m}^{2} \mathrm{~K}$ as the maximum thermal transmittance for walls for the case of Santiago. In construction terms, this would mean going from a brick masonry wall without thermal insulation to another that would incorporate at least $50 \mathrm{~mm}$ (assuming expanded polystyrene with a density of $20 \mathrm{~kg} / \mathrm{m}^{3}$ ). This proposed value was later limited to $0.8 \mathrm{~W} / \mathrm{m}^{2} \mathrm{~K}$ to be incorporated as a reference in the "Sustainable Construction Standards for Housing in Chile" [37], which is equivalent to a guide on best practices that do not constitute a binding commitment. However, the mandatory application of these standards-as part of the General Ordinance on Urbanism and Construction-has been indefinitely postponed despite a commitment in the current administration's Energy Agenda [38].

At the same time, since 2013, an "energy labelling" has been implemented in Chile, comprising an instrument that evaluates the energy efficiency of a home, considering its consumption of sanitary hot water for sanitation, lighting and heating. As a result, a rating has been established-which is formally very similar to the energy rating applied by the European Energy Performance of Buildings Directive [39] - with a ranking using letters from " $\mathrm{A}$ " to " $\mathrm{G}$ ", arranged from the most to least efficient, with " $\mathrm{E}$ " representing the construction standard contained in the current thermal regulation. To obtain it, a mechanism was established that mainly makes use of a simplified procedure by means of a steady-state calculation. While it was originally thought that the system would begin to be implemented gradually in 2016 [40], it was postponed indefinitely and thus became a voluntary practice. However, there has been very low adoption by the market. For example, in terms of the final rating (that is, for homes that have obtained final municipal acceptance), only $5.5 \%$ correspond to the private market. In absolute terms, this translates into 594 homes in all of Chile since the system began in 2013 until January of 2017 (Table 1) [41], which is clearly marginal in comparison with the total housing market stock, which at the national level fluctuated between 70,500 and 101,300 units during the same period according to data from the Chilean Chamber of Construction [18]. The number increases to 3945 homes if energy prequalification is considered (for which it is sufficient to have an approved building permit)—constituting the main strategy chosen by real estate agencies for promotion purposes during the sales phase-which, however, reveals that the positioning of this tool in the real estate market has been very weak.

Thus, given that the national market has not adopted an objective tool such as energy labelling or other certification systems (such as the LEED or Passivhaus systems [42,43]) on a large scale to inform consumers about energy efficiency in residential real estate transactions, the chosen approach for communicating competitive advantages in terms of sustainability has been based on their attributes. In this way, under the logic of the market, it would be expected that housing developments with more or better efficiency attributes receive a market premium with the understanding that the marginal benefits (for example, associated with the costs avoided in energy consumption for heat or sanitary hot water) are equal to the marginal costs for improvements to thermal enclosure and/or more efficient systems. According to this logic, real estate developers have generated their products on the basis of these attributes, generating the internalization of urban attributes and establishing differentiated products according to their spatial location. 
Table 1. Number of prequalified and qualified homes in the country up to January 2017 using the energy labelling tool based on the letter obtained. Percentage obtained with regard to the total of each type by column.

\begin{tabular}{cccccccccc}
\hline & & \multicolumn{2}{c}{ A and B Ratings } & \multicolumn{2}{c}{ C and D Ratings } & E, F and G Ratings & \multicolumn{2}{c}{ Total } \\
\cline { 3 - 10 } & & $N$ & $\%$ & $N$ & $\%$ & $N$ & $\%$ & $N$ & $\%$ \\
\hline Private & Prequalification & 1047 & $95.4 \%$ & 1900 & $20.4 \%$ & 998 & $12.7 \%$ & 3945 & $21.6 \%$ \\
housing & Qualification & 94 & $81.0 \%$ & 402 & $9.0 \%$ & 98 & $1.6 \%$ & 594 & $5.5 \%$ \\
\hline Public & Prequalification & 50 & $4.6 \%$ & 7083 & $75.9 \%$ & 6626 & $84.6 \%$ & 13,759 & $75.4 \%$ \\
housing & Qualification & 22 & $19.0 \%$ & 4028 & $90.2 \%$ & 5974 & $96.3 \%$ & 10,024 & $93.0 \%$ \\
\hline Mixed & Prequalification & 1 & $0.1 \%$ & 344 & $3.7 \%$ & 205 & $2.6 \%$ & 550 & $3.0 \%$ \\
housing & Qualification & 0 & $0.0 \%$ & 34 & $0.8 \%$ & 132 & $2.1 \%$ & 166 & $1.5 \%$ \\
\hline \multirow{2}{*}{ Total } & Prequalification & 1098 & $100.0 \%$ & 9327 & $100.0 \%$ & 7829 & $100.0 \%$ & 18,254 & $100.0 \%$ \\
& Qualification & 116 & $100.0 \%$ & 4464 & $100.0 \%$ & 6204 & $100.0 \%$ & 10,784 & $100.0 \%$ \\
\hline
\end{tabular}

\section{Theoretical Framework}

\subsection{Understanding the Concept of Real Estate Attributes}

By definition, attributes can be understood as those characteristics of a real estate product that are capable of differentiating housing and contributing to the construction of value. Meanwhile, from an economic perspective, "value" can be defined as the perception of consumers with regard to a given good, making it possible to establish their willingness to pay for it. In effect, according to Adam Smith [44], this concept, according to its characteristics and restrictions, can be called "use value", understood as the utility of a particular object, or "exchange value" (p. I.4.13), which has to do with the characteristics of a product as understood between its monetary value and that perceived by the consumer. These values can be related in a dialectical manner, encapsulating elements of valuation by sellers and consumers, such that-as Harvey states [45] referring to Marx- "they take on meaning (come into existence if you will) through their relationship to each other (and to other concepts) and through their relationship to the situations and circumstances under discussion" (p. 154).

However, real estate products differ greatly from traditionally mass-produced products such as automobiles or household items. In effect, although homes may be partially industrialized-due to the presence of prefabricated components-they belong to a scale of production that is far from that of mass-produced products. In other words, "without the economies of scale of a Procter \& Gamble or a Ford Motor Company, real estate developers cannot create their products as efficiently as other markets" [46] (p. 7). Meanwhile, according to the same authors, the real estate product is distinguished-above all—"by the importance of location". This can be observed, for example, in the fact that sales prices are defined in relation to placement, both in terms of physical characteristics (e.g., the size and shape of the site) and locational ones (e.g., the proximity of public transportation, schools, health facilities, parks or plazas).

Consequently, housing products in particular can be understood as the sum of their attributes, which can be those of a real estate project, or assume, individually, "external circumstances of diverse origins (urban amenities; social, cultural or market considerations, etc.)" [47] (p. 139). The latter cannot be modified, as, for example, a specific location has standards associated with its micro-locational aspects such as the district in which it falls, while those of a project can generate a product design by aggregation based on the different attributes the real estate developer wishes to deliver. Thus, in markets with little regulation, "this is reflected in a project that balances its attributes to maintain similar price ranges in different locations" [48] (p. 72).

Sustainability attributes appear in this context, prompting a discussion about their effective capacity for differentiation between real estate products that include them and their immediate competition. In the case of the Santiago real estate market, it should be noted that-despite the absence of mandatory energy certification-real estate differentiation has emphasized these architectural 
characteristics over traditional ones based on the functional layout, common areas or the quality of the finishings.

\subsection{The Configuration of Real Estate Prices}

In liberalized markets, real estate projects are created on the basis of a product that maximizes the power of attraction among potential buyers in accordance with the expected profit, taking into account the price of the land and construction costs. A proposed definition of real estate prices is determined based on the relationship between two approaches: supply price and demand price, which constitute a binomial and influence one another mutually. Given that the conditions of this microeconomic relation are not in perfect equilibrium, this balance is generated based on the monopoly of the location and the generation of maximum price ranges from demand.

In addition to this, perception of demand is influenced by the real estate promotion but also the commercial attraction of projects depends on the consumer access to the offered prices. These are determined by the elasticity of both supply and demand, which are associated with the margin of utility expected by the investor and the present or projected capacity for payment by consumers. In simple terms, consumers buy what they can afford, which in economic terms is expressed by the natural condition of the locational monopoly of a project.

Substitute projects compete with this at similar price or replacing location with other attributes. This monopoly rent is constituted in the merchandise or service produced-in addition to that of the land-some being transplanted by others and generating a new paradigm of analysis, which in its conceptualization of maximization of the utility of capital revaluates the real estate equation [49]. Following this argument, "competition" occurs between monopolists who change their markets to differentiate themselves - through the design of their real estate product-from their base product to the associated services, to the imaginary of urban housing or the symbolic component [16] and the means of commercialization they utilize. This "monopolistic competition" between products configures a real estate supply with levels of differentiation at the level of attributes and market approaches.

The design of the product is based on the incorporation of the attributes associated with the valuation and its cost or contribution to the total cost of the home, that is, the relationship between supply price and demand price. In a liberalized real estate market, there is a monopolistic competition with clear elements of differentiation and compensation of attributes. In other words, each project configures its "supply" of property attributes, based on the ability to exercise its monopoly power related to location and having sufficient demand associated with the payment capacity of consumers.

In this context, energy certification can also be understood as an attribute, since it supports the construction of buildings with higher energy-efficiency standards through its indirect promotion. This approach is based on the understanding that energy-savings positively affect the willingness to pay for efficient buildings, thus leading to higher prices enough to offset production costs and thereby encouraging developers. In other words, it allows capturing the increase of the economic value of energy efficient buildings [50], which has also been explored related to environmental externalities [51]. For example, the pioneering research of Dinan and Miranowsky [52] revealed that improvements in energy efficiency applied in the real-estate market in Des Moines, Iowa, equaled a reduction in energy consumption of 1 USD (while maintaining the house at a comfortable temperature of $18^{\circ} \mathrm{C}$ ), which represented a market premium of 11.63 USD in price. In recent years, subsequent studies have addressed the impact of energy labelling on real-estate prices, such as the Energy Star certification [53-56], the LEED (Leadership in Energy and Environmental Design) scheme [55,56], the Energy Performance Certificates (EPC's) from the European Energy Performance of Buildings Directive [57-64], and others schemes [65], by identifying different levels in the market premiums associated with better-ranked homes. For example, the study by Bio Intelligence Service [66] - commissioned for the purpose of assessing the European Directive-reveals that the effect of each of the EPC label levels (expressed in letters) on the price ranges from $0.4 \%$ in Oxford to $11 \%$ in Vienna; it is $4.3 \%$ in Marseille, $3.2 \%$ in Lille and $2.9 \%$ in Brussels. In this sense, this schemes also may provide an additional premium over 
non-certified space that identifies_-by means of individual attributes—as sustainable or green, as it has been identified, for example, for LEED market-rate apartments in the United States [67].

However, unlike most of the research performed in the previously noted developed countries, it is difficult to analyze price formation using methods based on observed preferences (as in the econometric models used in these studies or using the Market Comparison Approach, as in the study from De Ruggiero et al. [68]) in areas in which there are few energy-certified buildings, such as in the Chilean case. In addition to this, there is a restricted access to the transaction price, so although some attempts have been made to develop a hedonic price model, they tend to be inconclusive or very out of date in temporal terms since property register-transaction prices are often outdated. However, previously published research by the authors-using a simplified regression analysis in comparison to [69] — revealed that, also in the case of Santiago, attributes such as double glazing, solar thermal collectors, photovoltaic panels and/or water-saving appliances have a positive impact on the value of buildings [48]. However, said impact is not uniform across different segments of the residential market: it is null in the cheapest properties, possibly because their developers cannot afford the added cost of construction, and it is scant in the upper-middle and upper strata, where said attributes do not represent real estate differentiation because they are present in a large part of the housing stock. However, the impact is significant in housing associated with the middle-income sectors, where it is possible that the operating costs avoided, and the non-financial benefits associated with reduced environmental impact play a role in favor of the production of housing promoted as "sustainable". This latter aspect is especially relevant for the most exclusive homes because owning such a home could entail psychosocial rewards in their market niche. This kind of impact, however, has not been always find, as in the study by Freybote, Sun and Yang [70], where the intangible labelling effects of LEED neighborhood certification do not lead to a market premium (in opposition to the financial benefits of LEED building scheme, which effectively add a premium to condominium sales prices).

\section{Methodology}

For this study, a methodology consisting of two exploratory approaches was utilized to investigate real estate attributes in the housing market of Santiago. First, a cross-sectional analysis was conducted-understood as a research design that collects data at a single moment in time- to study the cross-validation of attributes (in terms of supply and demand) in two housing microsectors during the months of August, September and October of 2016. These months were chosen because they consist of the period during which Santiago has the greatest amount of real estate for sale due to the launching of new products. Although the initial objective of this study was to observe this situation simultaneously in a single period of time, the exercise was repeated in the same months during 2017, providing a new perspective with regard to whether the initial diagnosis underwent modifications from one year to the next. Meanwhile, a longitudinal analysis was performed-defined as a research design that gathers data over time to make inferences regarding its evolution-to study the evolution of different sustainability attributes in real estate promotion over a period of five years (from July 2012 to July 2017).

To conduct the cross-sectional analysis of attributes based on a reading of territorial submarkets, two real estate microsectors were selected that are associated with residential building projects in the municipalities of Santiago and Las Condes, both of which belong to the Metropolitan Area (Figure 1). While both municipalities are increasing in density, there has been a significant change in the real estate products with which they are being developed. Being marketed in the municipality of Santiago are apartments with smaller square-footage, floor plans of one or two bedrooms, with a number of important indoor attributes (e.g., a gym, a multipurpose room, quincho or barbeque area and terraces), mid-range finishings and proximity to public transportation (metro and buses). Meanwhile, the situation in Las Condes is different; there, the buildings being marketed are higher on average, with greater square footage and a much higher standard of finishings. 


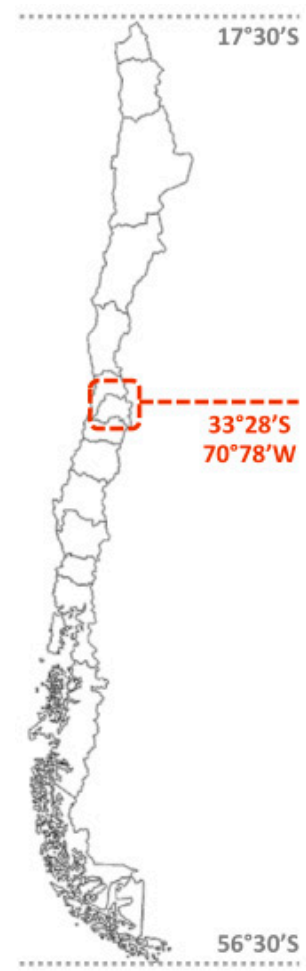

(a)

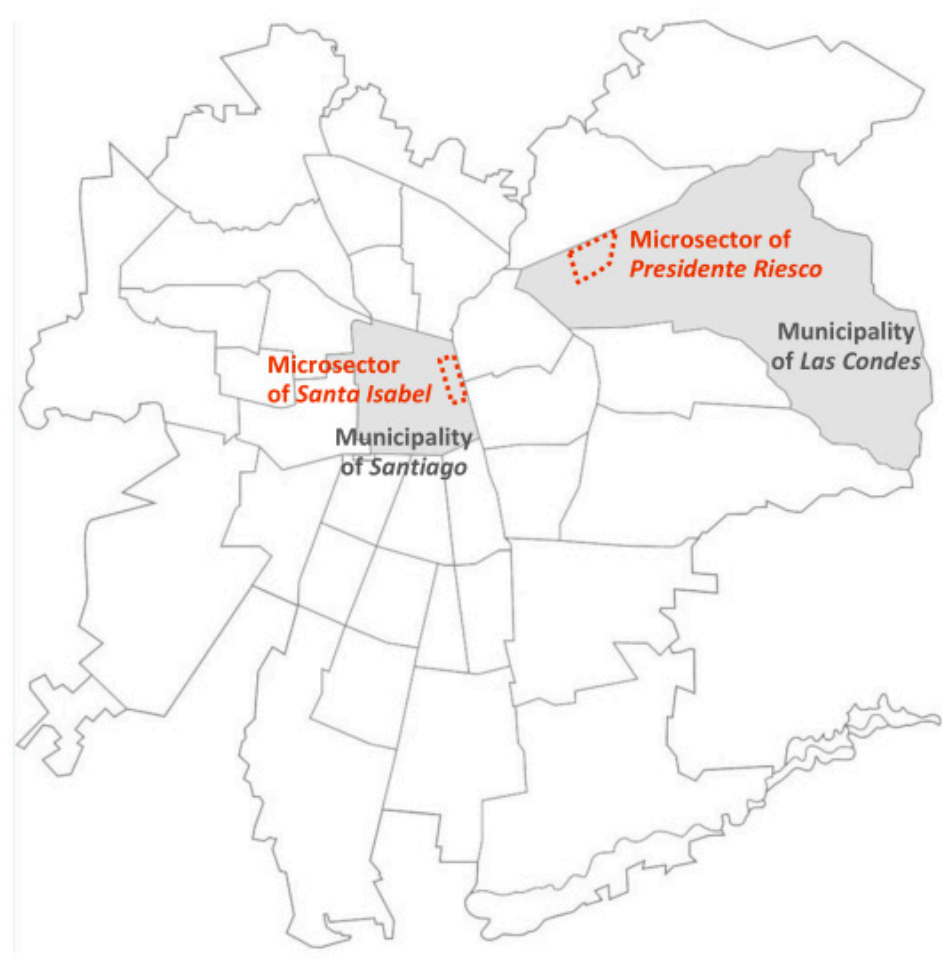

(b)

Figure 1. (a) Map of Chile with the location of Santiago; (b) The two real estate microsectors analyzed in the Metropolitan Area.

For the municipality of Santiago, the historic center associated with middle-income residents, the microsector of Santa Isabel was established. Additionally, for the case of Las Condes, located in the eastern part of town and associated with higher-income residents, the microsector of Presidente Riesco was selected. In both cases, the totality of the real estate stock was inventoried in residential buildings during the months of August, September and October in 2016 and 2017, based on advertisements that appeared on press, online and on the street, in addition to information gathered during site visits. Additionally, a questionnaire was given to consumers of housing in those sectors regarding the level of importance - evaluated through a Likert-type scale with 5 response levels -they assigned to each one of the real estate attributes identified in the survey. This was conducted online based on contacts established in sales rooms and real estate sales databases, which resulted in a sample of approximately 100 surveyed in both cases. According to this, a sample design was defined with a $95 \%$ confidence level and a $10 \%$ margin of error.

Second, for the longitudinal analysis, a survey of real estate promotion was conducted based on all of the advertisements that appeared in the magazine "Vivienda Decoración" by El Mercurio and the "Casas" supplement in Publimetro between January 2012 and July 2017. The first is a nationally circulating newspaper, while the second is a free paper distributed only in the metropolitan region of Santiago. A total of 8255 advertisements were surveyed. The basic data gathered for each one included the building in question, location and typology of the project, number of bedrooms and square footage offered, as well as offer prices (expressed in Chilean Unidades de Fomento, unit of account that is inflation-adjusted and widely utilized in the country to determine construction costs, home values and mortgage credits).

Meanwhile, all of the real estate attributes contained in the advertisements were identified, both those stated explicitly (through the text) and those suggested through images. The former included locational attributes (e.g., proximity to the metro, schools and health facilities), amenities (e.g., quincho or barbeque area, pool, multipurpose room), construction features (e.g., high-end finishing) and others. 
The latter include architectural attributes (e.g., terrace, patio) or those associated with the spatial qualities of the housing (e.g., spaciousness, light, views). In both cases, the presence of sustainability attributes in the advertising was evaluated (expressed as dummy variables; 0 for absence and 1 for presence), as well as the level of importance of each one of these in the advertisements (expressed as ordinal categorical variables, where 0 is "does not appear", 1 is "low importance", 2 is "medium importance" and 3 is "high importance"). To define the latter, a content analysis [71] was conducted, that considered the size, position and text of the message in the context of each advertising piece. Using this technique, the advertisements were studied with regard to their capacity to construct and convey narratives [72-74] from developers to consumers.

It should be noted that the definitions of sustainability attributes utilized in this study, especially in their broader senses—such as "sustainable", "energy efficient", or "ecological"—are determined by their interpretation in terms of supply and demand in the context of Santiago's real estate market. In this sense, the performance associated with these attributes is often not evaluated, or-if it is-consumers are not effectively informed in a clear and transparent manner. Indeed, guides to best practices that make it possible to adequately estimate and communicate the presence of these attributes-in the sense proposed by the national "Guide for the sustainable development of real estate projects" [14]—are very recent [37]. However, their application is not mandatory, and thus, there is a risk of greenwashing.

\section{The Cross-Validation of Attributes in Supply and Demand in Two Real Estate Microsectors}

To establish the presence of real estate attributes in the housing supply, as well as how they are perceived from the perspective of demand, a survey was carried out with regard to supply in the two proposed microsectors, and attribute valuation surveys were conducted among potential buyers. This was done with the objective of identifying the cross-validation of these attributes, especially those that pertained to sustainability, as well as to observe whether variations have occurred in both of the cases analyzed from one year to the next. Figures 2 and 3 present this valuation of supply versus demand for 2016 and 2017 in the microsectors of Santa Isabel and Presidente Riesco. In them, one can observe how the different attributes are strategically positioned with regard to four categories-expressed as quadrants-defined according to their presence in at least a half of the sample for both supply and demand. These are crossed, in addition, with a more functional classification in terms of sustainability attributes, locational attributes, and others. Subsequently, the 4 quadrants of these figures were defined as follows:

- Consolidated attributes (high presence in supply and important in demand)

- Emerging attributes (low presence in supply and important in demand)

- Disposable attributes (low presence in supply and little importance in demand)

- Uncertain attributes (high presence in supply and little importance in demand)

It is observed that the attributes of each category present variations between both microsectors during the same time period. This occurs because both markets present different strategies of positioning and valuations by real estate consumers, which focus on different prices and products. While in Santa Isabel, the commercial strategy is based on the variable of price and oriented primarily towards investors, in Presidente Riesco, the strategy is clearly one of differentiation and focused on the requirements of the end consumer. Based on the above, it is possible to infer that there are differences in the positioning of sustainability attributes in the two markets. For example, in the microsector of Santa Isabel, these attributes can be available and highlighted in the supply as long as they are able to add value to the product without significantly increasing the price. Hence, in the year 2016, "bicycle racks" (very low investment) and "bicycle paths" (an external attribute) are the only attributes that are positioned in the quadrant of consolidated attributes, while "double-glazed windows" and "green spaces" appear only as emerging attributes (Figure 2). However, in the following year, "double-glazed windows" changes to the consolidated category and "bicycle racks" falls to the emerging category, which can represent the presence of a competitive market. On the contrary, for the microsector of 
Presidente Riesco, the attributes that add value to the real estate product, at the same time increasing its offer price, such as "double-glazed windows", "green spaces" or "orientation", occupy the category of consolidated attributes in both 2016 and 2017 (Figure 3).

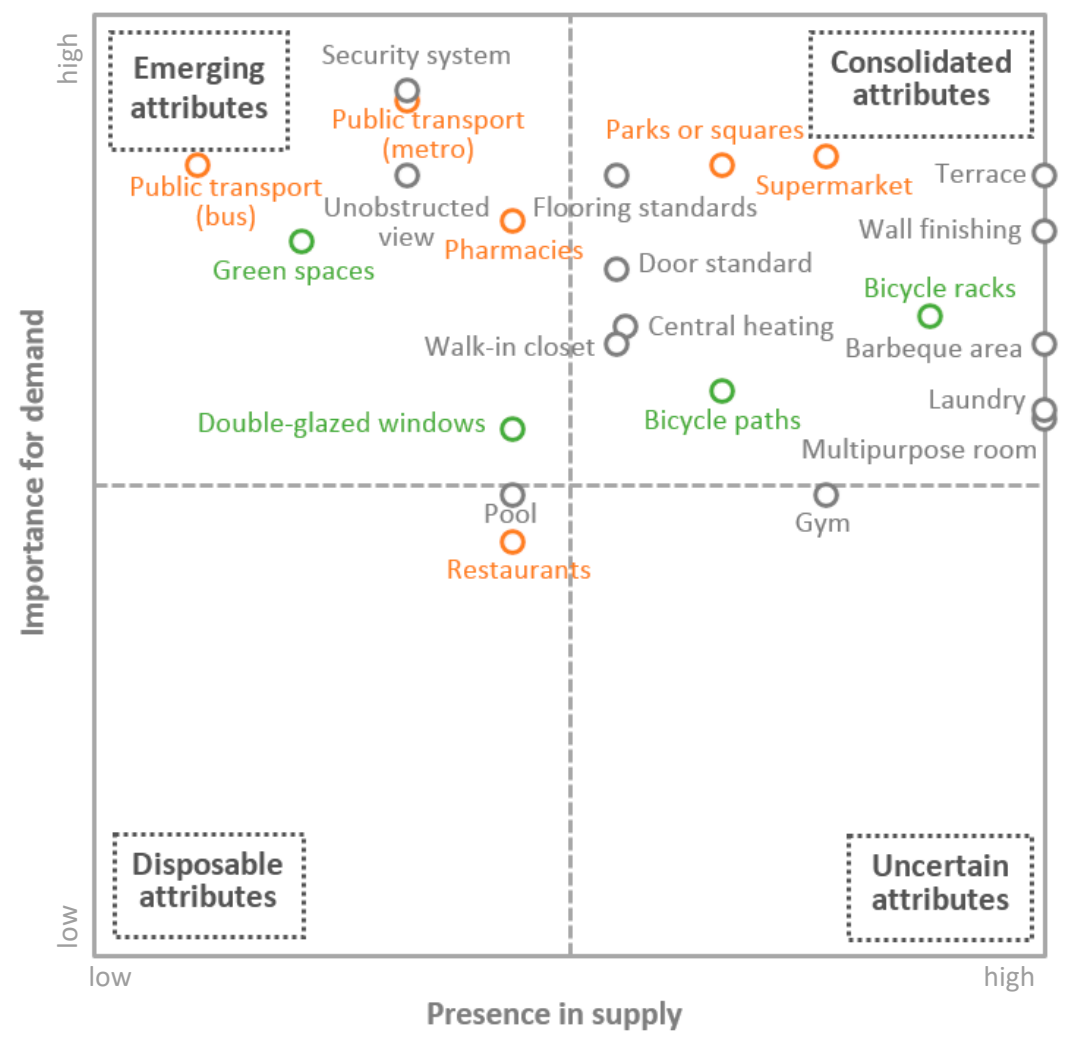

(a)

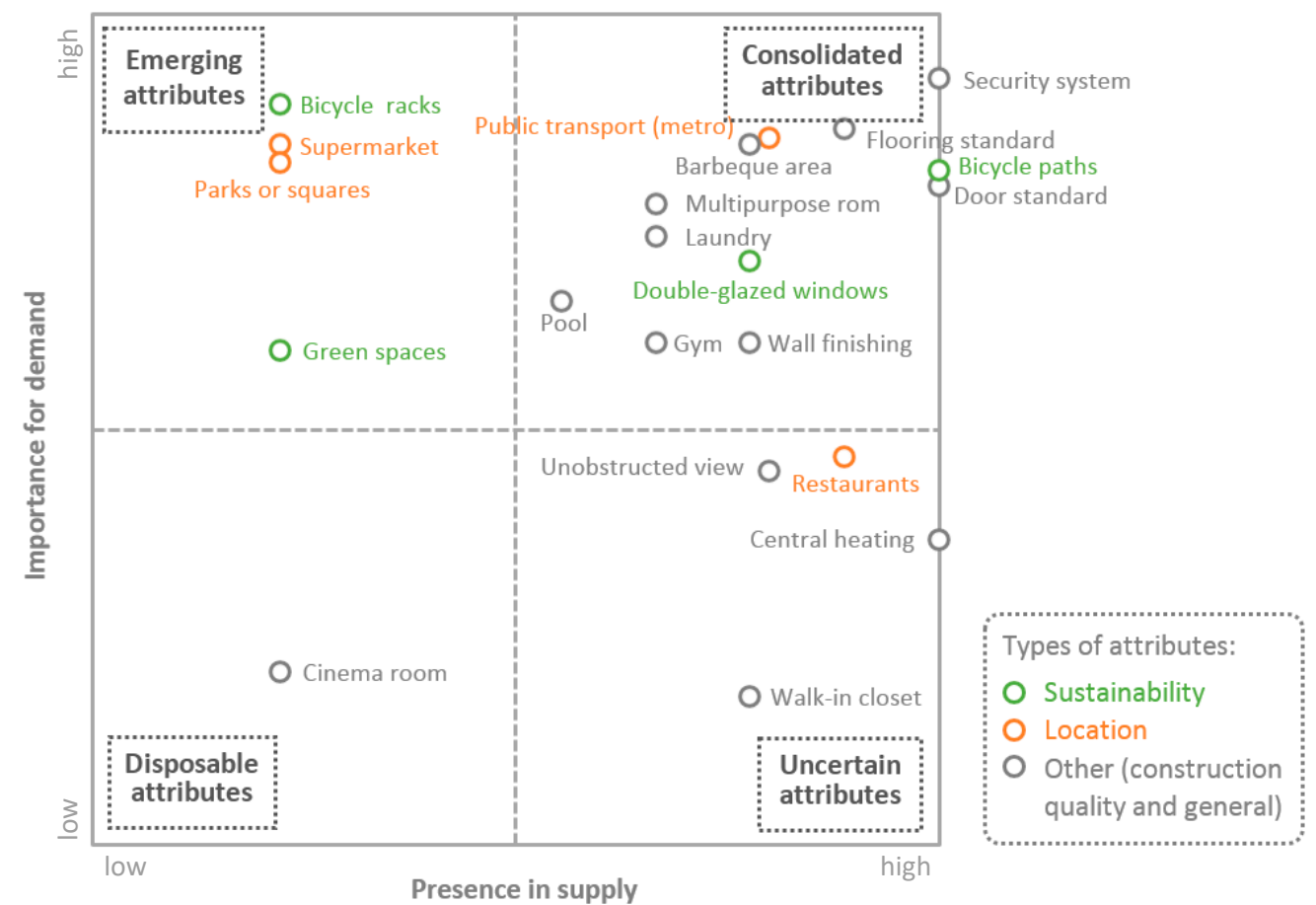

(b)

Figure 2. Valuation of attributes in supply and demand for the microsector of Santa Isabel in the months of August, September and October in the years (a) 2016 and (b) 2017. 


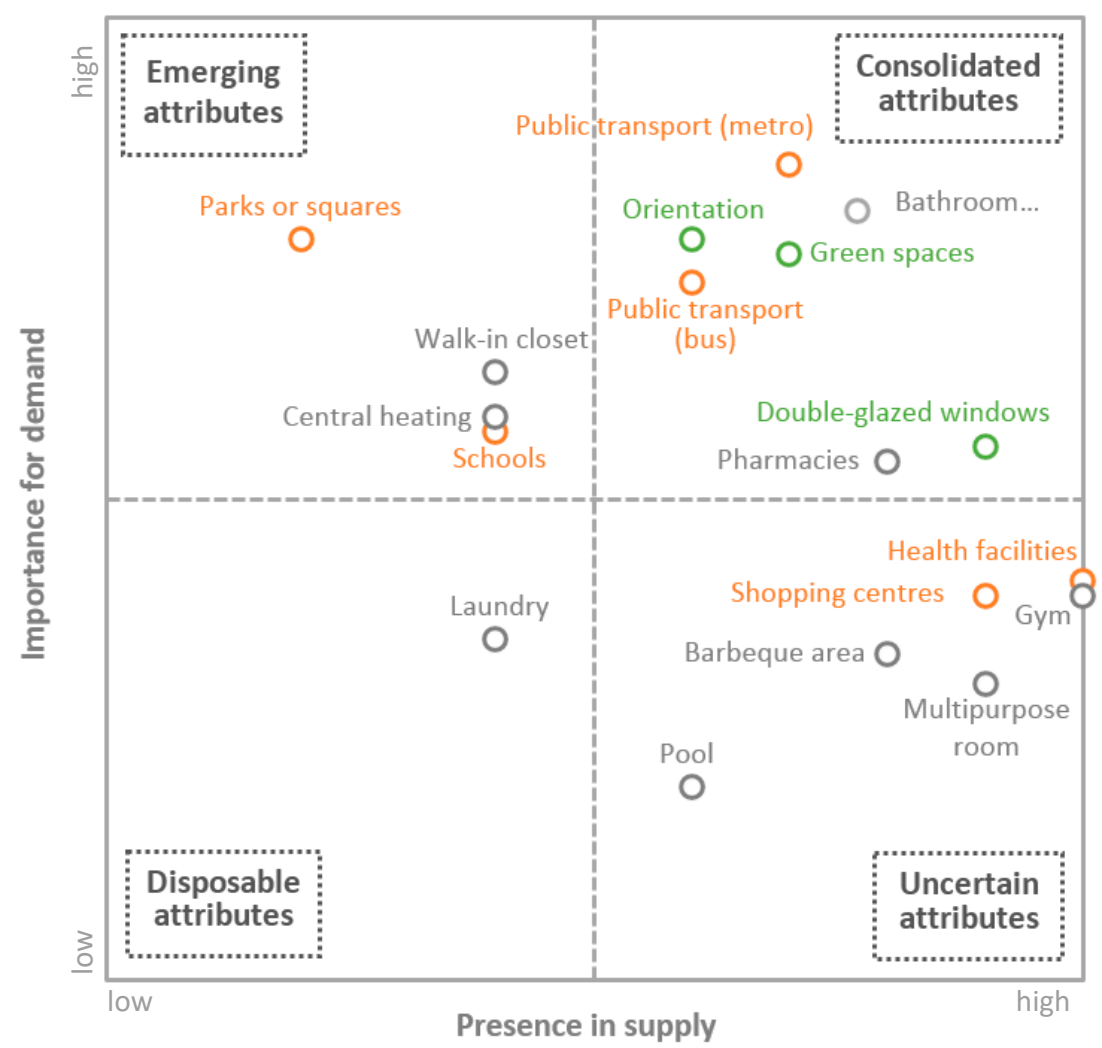

(a)

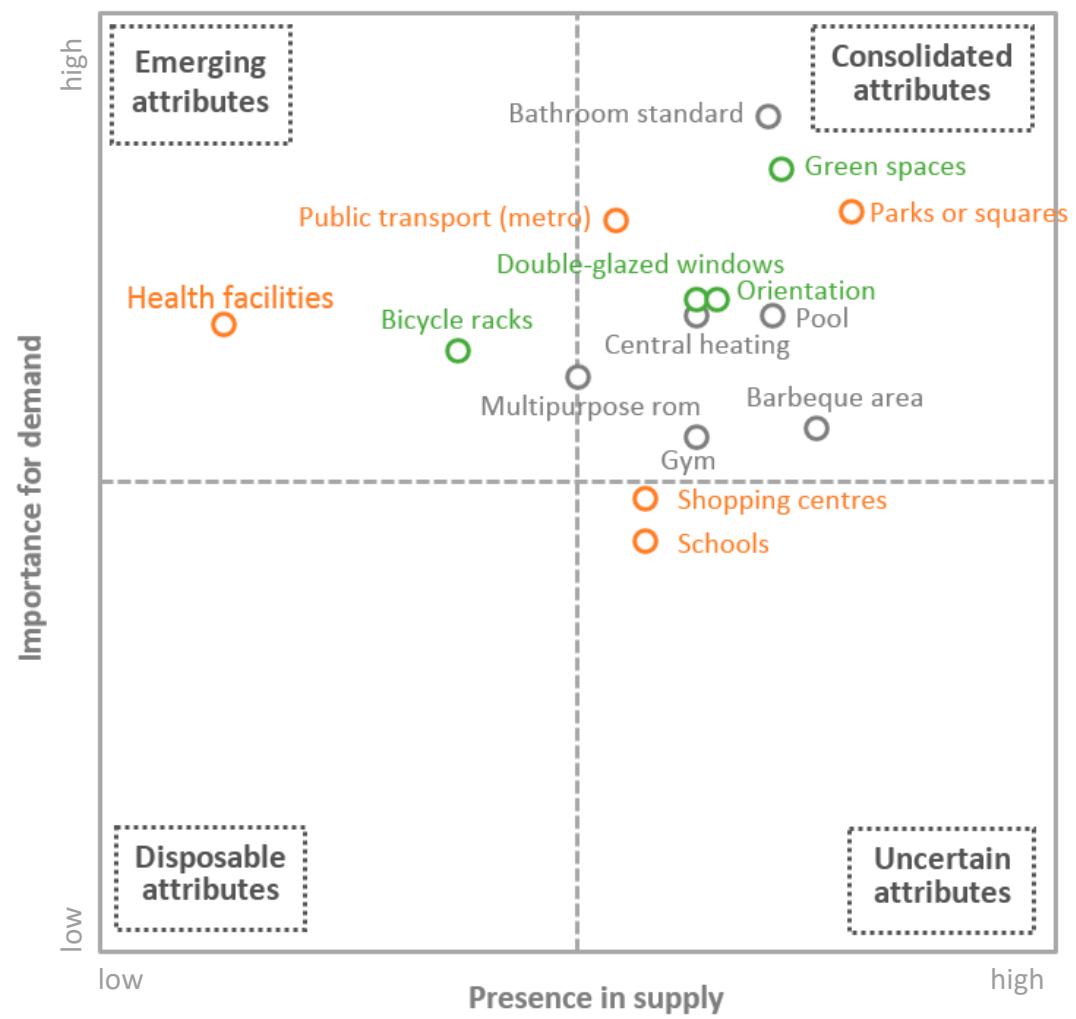
Types of attributes:
O Sustainability
O Location
O Other (construction quality and general)

(b)

Figure 3. Valuation of attributes in supply and demand for the microsector of Presidente Riesco in the months of August, September and October in the years (a) 2016 and (b) 2017. 
Nevertheless, it is equally interesting to observe the evolution presented by the attributes of sustainability in terms of their valuation (expressed in terms of their relative position in the quadrants) between 2016 and 2017 (Figure 4). In the case of the microsector of Santa Isabel, it is possible to observe how an attribute that were previously classified as emerging ("double-glazed windows") appears one year later as consolidated, revealing this to be a submarket of great dynamism. On the contrary, the attribute of "bicycle racks" Although the investor-oriented marketing strategy was mentioned above, it can also be understood in terms of the differentiating capacity that these attributes can have, encouraging their incorporation by developers. However, in the microsector of Presidente Riesco, major changes are not observed in the positioning of existing sustainability attributes or the incorporation of new ones, excepting for the case of "double-glazed windows", which decreases in terms of its presence in supply despite the fact that it increases its level of importance for demand. This could represent a warning sign, since, being a subsector primarily oriented towards the end consumer, differentiation should also be sought, which currently appears to be associated more with design attributes than sustainability (although they are still not fully understood by consumers).

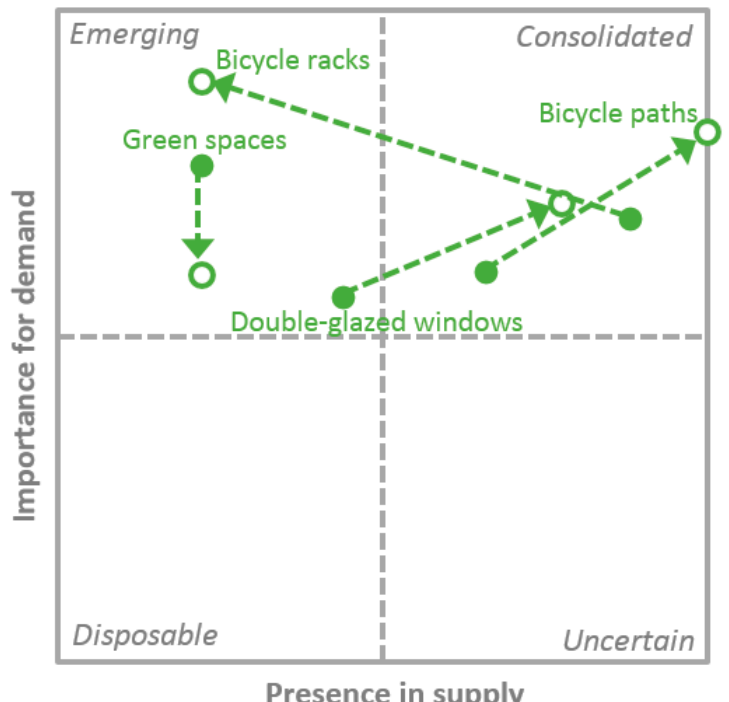

(a)

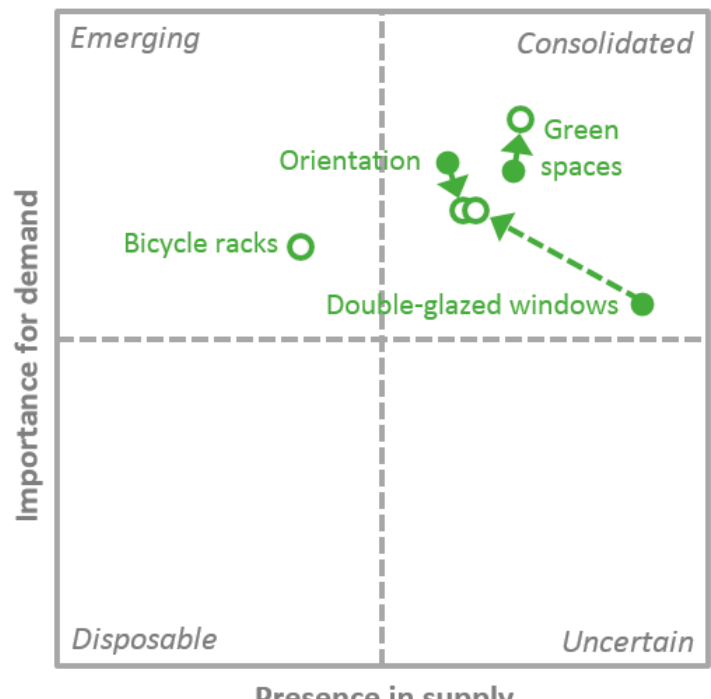

(b)

Figure 4. The evolution of the positioning of sustainability attributes with regard to the valuation of supply and demand, in 2016 and 2017, for the real estate microsectors of (a) Santa Isabel and (b) Presidente Riesco.

The dynamism of this logic of attributes in the real estate market generates the risk that at any point some type of attribute will lose relevance or become "no longer in fashion" - such as in the case of "bicycle racks" for the microsector of Santa Isabel—as indicated by some of those surveyed in the sales room. The longitudinal analysis that will be presented in what follows attempts to shed light on this issue, especially in the national context in which the promotion of sustainability in real estate occurs through individual attributes, masking weak energy regulation and a system of voluntary energy rating that is adopted at very low rates by the industry.

\section{The Evolution of Sustainability Attributes in Real Estate Promotion}

Bourdieu's work [16] represents one of the most systematic efforts to understand the way in which real estate companies distinguish themselves "for the scale of the symbolic campaigns of transfiguration mounted by their commercial departments (particularly their advertising departments but also their sales forces) to make good the potential gap between the product as actually supplied and perceived and the expectation of that product and to convince clients that the product on offer is made 
for them and they are made for that product" (p. 54). Through the analysis of real estate advertising in the 1980s in France, he studied the way in which print advertisements are able to promote an imaginary regarding real estate and the different lifestyles it represents. In this way, the study of real estate promotion is understood as an element capable of mediating-through communication-between the imaginary proposed by the developer for a project and its potential consumers.

The liberal economy model has posed a complex process of definition between these messages and how they are positioned in consumers and their decisions. Therefore, a longitudinal analysis of the evolution of this marketing discourse, understood as a symbolic action, is relevant in establishing consumers' valuations in this regard. Just as Bourdieu identifies and interprets marketing strategies around the concept of the "traditional mode of production" (p. 22) —as a way to mask the impersonality imposed by mass-scale building-by using such strategies to promote sustainability in real estate, one can warn of the risk of greenwashing. This is the case, especially when the condition of sustainability of a project (and therefore its promotion) is based solely on individual attributes without validated information, as opposed to the possibility of having an objective and transparent tool with which to help consumers avoid information asymmetry, such as some kind of environmental or energy certification [75]. The international experience-especially based on European energy ratings—suggests that these instruments are capable of incentivizing the market to move towards the provision of real estate products with greater levels of energy efficiency, observed, for example, in the generation of market premiums.

However, an important difference is generated when the promotion of sustainability in real estate is conducted based on conceptual or abstract attributes, without being supported by technical arguments. While industry best practices recommend avoiding subjective general statements in real estate advertising—such as "sustainable", "green" or "ecological" [14] (p. 124)—cases are observed in which projects that are expressly declared "energy efficient" or "sustainable" are presented alongside others that could in fact represent certain evidence or measure of energy efficiency or sustainability. Table 2 shows how, in the projects presented as "energy efficient" or "sustainable" within the database of real estate advertisements collected, there are many more cases that do not appear to be associated with other individual attributes that provide arguments regarding their energy efficiency or sustainability ("double-glazed windows", "thermal solar collectors", "energy certification", "water-saving appliances" and "EIFS-type thermal insulation"). This is reflected, for example, in the fact that $74.9 \%$ of the projects that are presented as energy efficient do not possess-or state that they possess-any type of energy certification that could represent a guarantee of this condition (which would be desirable from the consumer's point of view). However, these also do not guarantee by themselves the energy efficiency or sustainability of the project. For example, while it could be generally desirable to incorporate double-glazed windows in a residential context, it would depend on many other variables in form and construction (for example, orientation, percentage of glazing, level of insulation in exterior walls) for this to constitute an effective contribution to the energy efficiency of housing) compared to those that do.

Moreover, there is another approach in which advertisements are based on technical arguments, as with the 1986 advertisement in Maison Dégut presented by Bourdieu [16], which describes the strength of "triple laminate load-bearing panels" and highlights their advantages in terms of thermal insulation and ventilation (p. 59). Similarly, the advertisement in Figure 5 presents as central the definition of the attributes thermal insulation, double-glazed windows and water-efficient appliances, incorporating the estimated savings in heat and water consumption. At the same time, the advertisement includes 3 of its own concepts ("E-House", "E-Energy" and "E-Water") with an image of a seal, although these aspects are not associated with any of the independent certifications most commonly used in Chile. 
Table 2. Projects declared "energy efficient" and "sustainable" versus the presence of individual attributes in the real estate promotion database $(N=8255)$. Percentage obtained with respect to the total for each attribute.

\begin{tabular}{|c|c|c|c|c|c|}
\hline & & \multicolumn{2}{|c|}{ Energy Efficient } & \multicolumn{2}{|c|}{ Sustainable } \\
\hline & & No & Yes & No & Yes \\
\hline \multirow{3}{*}{$\begin{array}{c}\text { Double-glazed } \\
\text { windows }\end{array}$} & No & $95.2 \%$ & $76.6 \%$ & $94.4 \%$ & $98.8 \%$ \\
\hline & Yes & $4.8 \%$ & $23.4 \%$ & $5.6 \%$ & $1.2 \%$ \\
\hline & Total & $100.0 \%$ & $100.0 \%$ & $100.0 \%$ & $100.0 \%$ \\
\hline \multirow{3}{*}{$\begin{array}{c}\text { Solar thermal } \\
\text { collectors }\end{array}$} & No & $95.9 \%$ & $73.7 \%$ & $95.2 \%$ & $81.8 \%$ \\
\hline & Yes & $4.1 \%$ & $26.3 \%$ & $4.8 \%$ & $18.2 \%$ \\
\hline & Total & $100.0 \%$ & $100.0 \%$ & $100.0 \%$ & $100.0 \%$ \\
\hline \multirow{3}{*}{$\begin{array}{c}\text { Energy } \\
\text { certification }\end{array}$} & No & $99.2 \%$ & $74.9 \%$ & $98.6 \%$ & $81.8 \%$ \\
\hline & Yes & $0.8 \%$ & $25.1 \%$ & $1.4 \%$ & $18.2 \%$ \\
\hline & Total & $100.0 \%$ & $100.0 \%$ & $100.0 \%$ & $100.0 \%$ \\
\hline \multirow{3}{*}{$\begin{array}{l}\text { Water-efficient } \\
\text { appliances }\end{array}$} & No & $99.4 \%$ & $78.6 \%$ & $98.8 \%$ & $86.7 \%$ \\
\hline & Yes & $0.6 \%$ & $21.4 \%$ & $1.2 \%$ & $13.3 \%$ \\
\hline & Total & $100.0 \%$ & $100.0 \%$ & $100.0 \%$ & $100.0 \%$ \\
\hline \multirow{3}{*}{$\begin{array}{c}\text { EIFS-type } \\
\text { thermal } \\
\text { insulation }{ }^{1}\end{array}$} & No & $99.6 \%$ & $92.5 \%$ & $99.3 \%$ & $100.0 \%$ \\
\hline & Yes & $0.4 \%$ & $7.5 \%$ & $0.7 \%$ & $0.0 \%$ \\
\hline & Total & $100.0 \%$ & $100.0 \%$ & $100.0 \%$ & $100.0 \%$ \\
\hline
\end{tabular}

${ }^{1}$ Acronym of "Exterior Insulation Finishing System", corresponding to construction systems that incorporate thermal insulation on the exterior of a wall, generally with heavy material, and including exterior cladding).
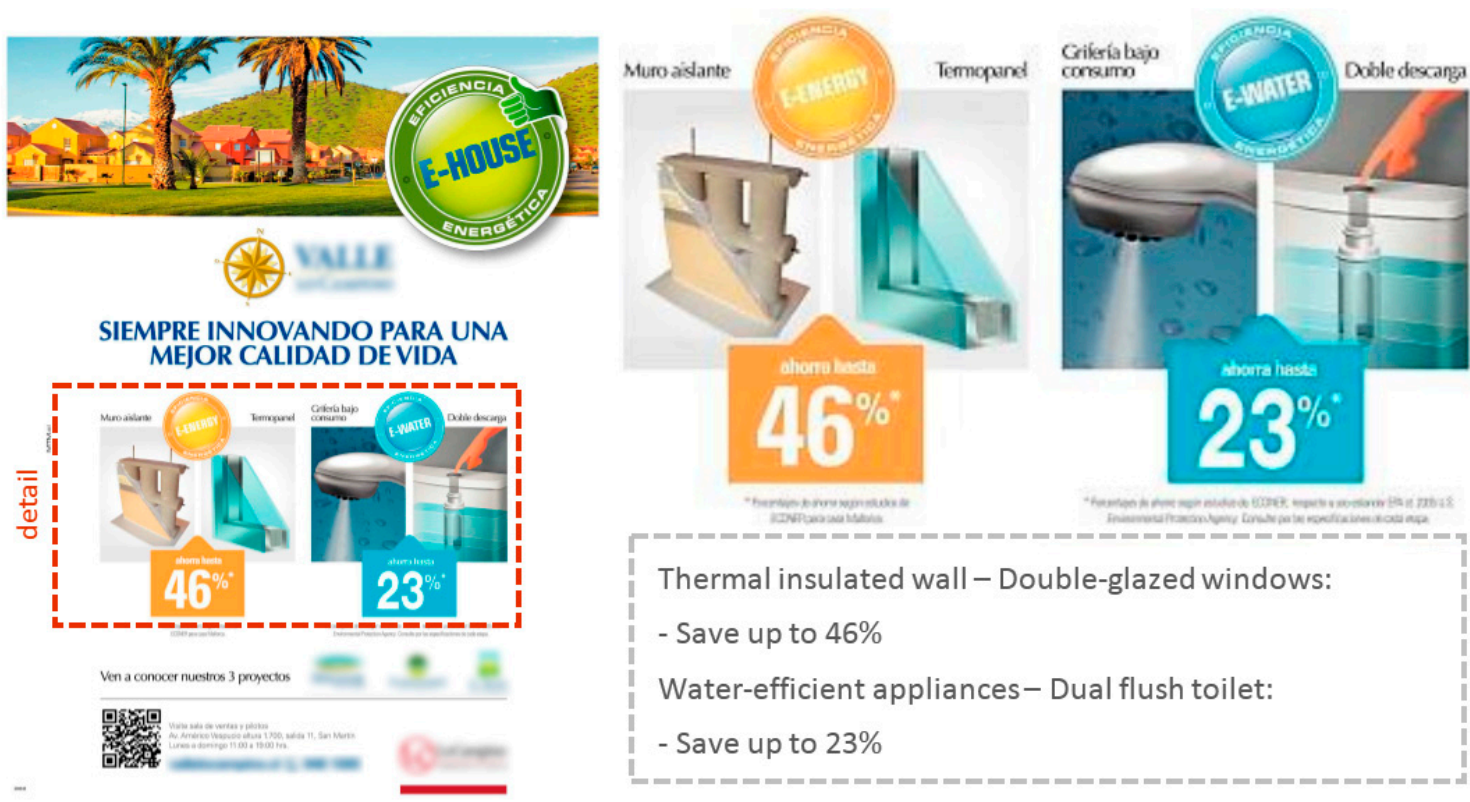

Figure 5. Advertisement for a set of homes with the attributes "thermal insulation", "hermetic double-glazed windows" and "water-efficient appliances". Notes: left: complete advertisement; right: detail. Commercial mentions appear blurred. Source: "CASAS" supplement in Publimetro, print edition, 3 August 2012, p. 23.

Further, Figures 6-8 present advertisements in which the list or details of sustainability attributes is replaced by some type of energy and/or environmental certification. In the first instance, it is mentioned that the project is "in the process of LEED certification", although the central message is that it is a "fully ecological building" (Figure 6). In this way, the certification would constitute the proof that reinforces this message, although no further details are provided regarding the specific type of LEED certification applied for or the level of certification to which the project aspires, instead substituting 
the imaginary associated with a green, leafy tree. It is interesting to observe the advertising approach utilized by the same real estate company 5 years later in an advertisement with similar characteristics (Figure 7). In this case, the message that the building is "in the process of LEED certification" is maintained, although the concept that reinforces or complements it is that of an "eco-efficient building", making use of a narrative that appears to an imaginary of sustainability. Meanwhile, the project in Figure 8 is associated with the energy labelling by the Ministry of Housing and Urban Planning, showing the average rating obtained in a central place in the advertisement. This is presented in strict accordance with the instructions in the brand manual for the tool [76]. In this case, as in the previous ones, certification reinforces another message-expressed in terms that can be easily understood by the potential consumer-corresponding to the idea of a "unique housing project in Chile with more than $50 \%$ energy savings". However, above energy efficiency or sustainability, this advertisement highlights what Ruiz-Tagle and López Morales call "the ideal of the nuclear family with the racial features of the Chilean elite: white skin, European features, tall and with light hair" [77] (p. 3), that is, an imaginary of the family and lifestyles characteristic of this type of advertising.
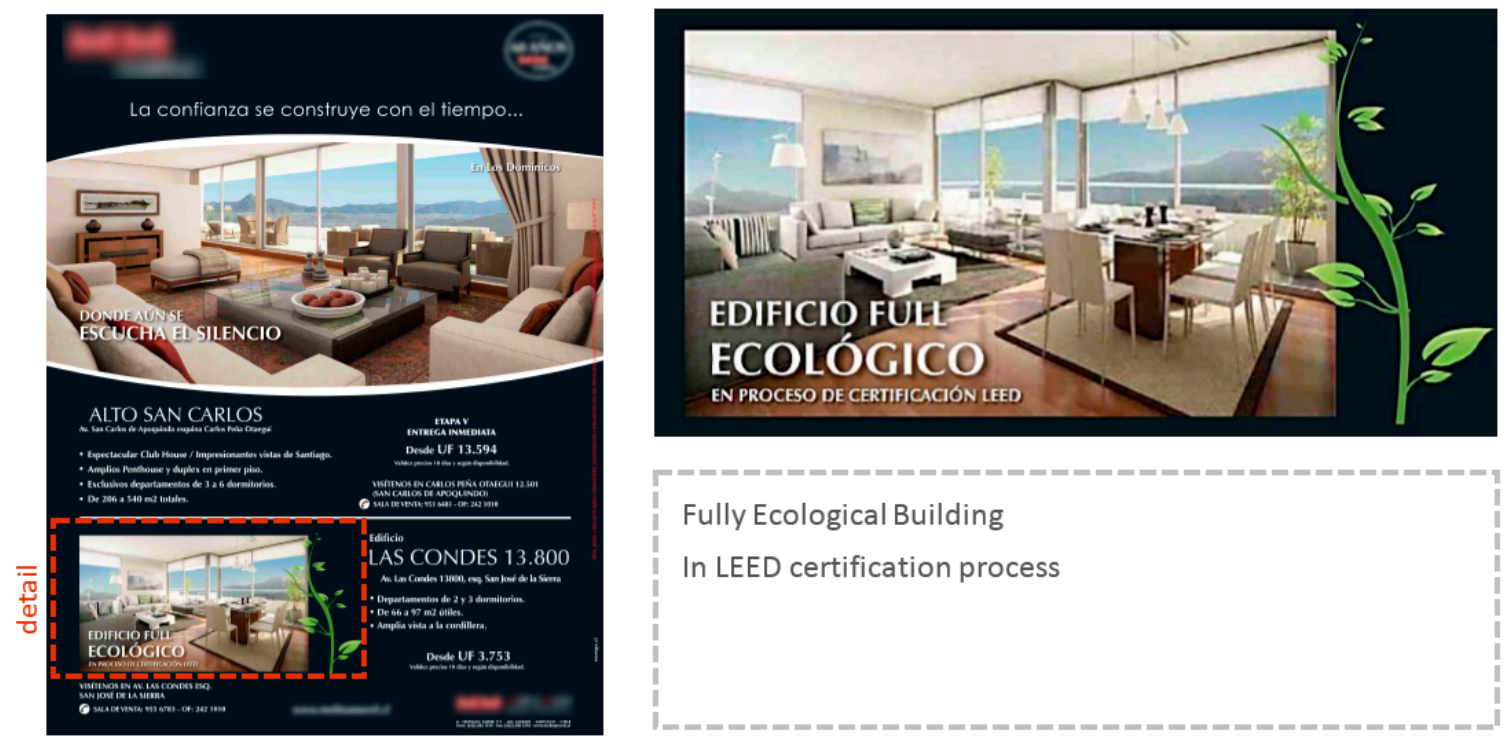

Fully Ecological Building

In LEED certification process

Figure 6. Advertisement for an apartment building with the attribute "energy certification". Notes: left: complete advertisement; right: detail. Commercial mentions appear blurred. Source: "Revista Vivienda y Decoración" in El Mercurio, print edition, 23 June 2012, p. 39.

Having observed the presence of sustainability attributes in certain print-form real estate advertisements and their communication strategies, it is pertinent to establish their positioning at a general level. The result obtained for the total number of projects in the database of real estate advertising $(N=8255)$ presents a general snapshot of the presence of these attributes in the discourses that emanate from the supply, highlighting the attributes "double-glazed windows", "thermal solar collectors", "bicycle racks", "energy certification", "natural light" and "water-efficient appliances" as those that appear most frequently (Figure 9). While their overall penetration rate is low (between $5.6 \%$ and $1.4 \%$ ), the condition of complex good that defines real estate products suggests that this positioning could occur differently in different market niches as a result of consumers' current and projected payment capacity or income. For the purposes of this study, the segments represented are homes under US $\$ 80,000$, between US $\$ 80,000$ and US $\$ 170,000$, and over US $\$ 420,000$. These represent consumers with different acquisitive power, and, in a city as residentially segregated as Santiago, different territorial submarkets. In this way, in broad strokes, we can associate the segments of under US $\$ 80,000$ and over US $\$ 420,000$ with the microsectors of Santa Isabel and President Riesco, respectively. The intermediate range would typically be associated with middle-income socio-economic sectors. 

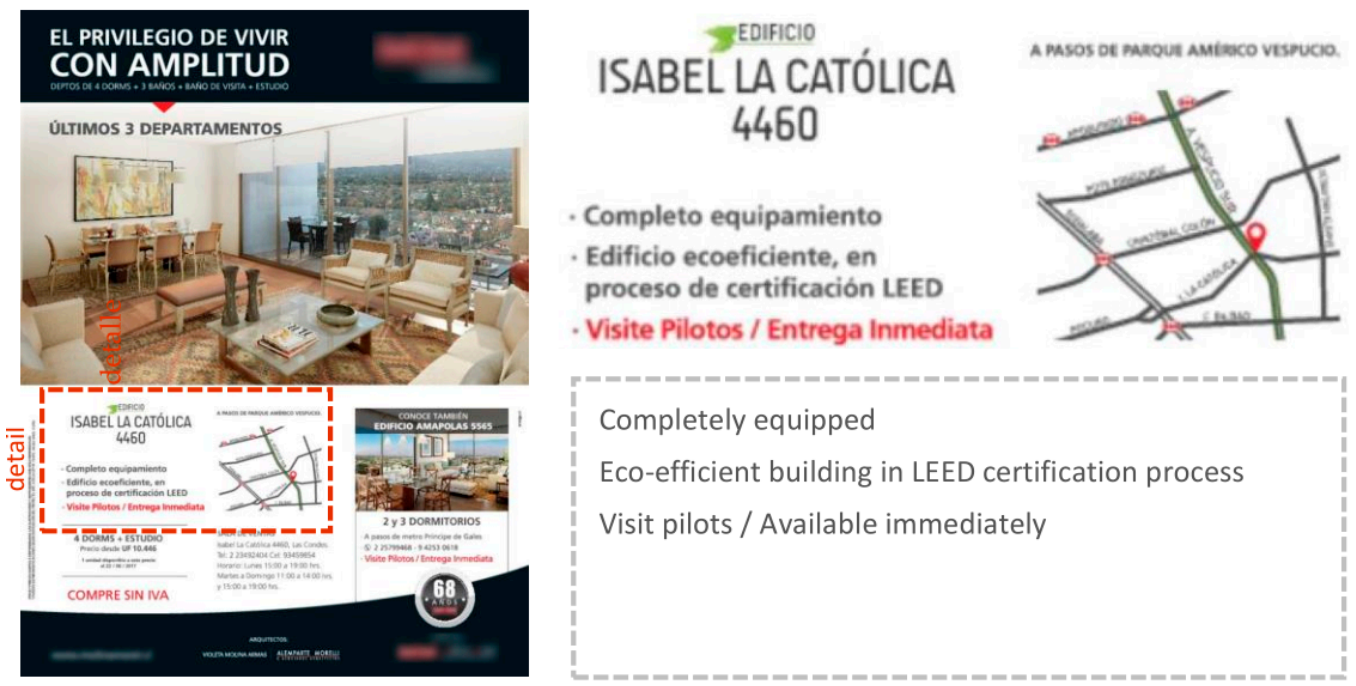

Figure 7. Advertisement for an apartment building with the attribute "energy certification". Notes: left: complete advertisement; right: detail. Commercial mentions appear blurred. Source: "Revista Vivienda y Decoración" in El Mercurio, print edition, 27 May 2017, p. 37.
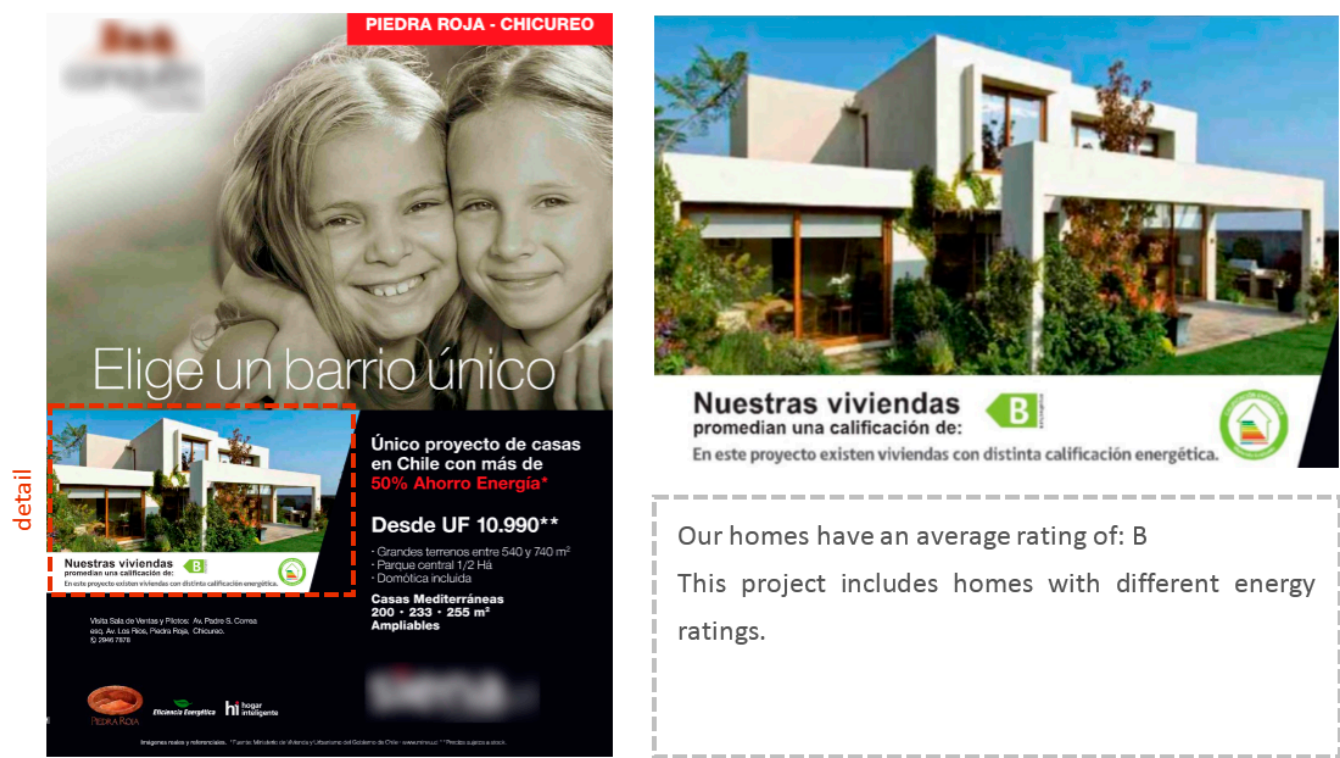

Our homes have an average rating of: $B$

This project includes homes with different energy ratings.

Figure 8. Advertisement for a set of homes with the attribute "energy certification". Notes: left: complete advertisement; right: detail. Commercial mentions appear blurred. Source: "Revista Vivienda y Decoración" in El Mercurio, print edition, 7 December 2013, p. 29.

Based on the cross-sectional analysis conducted, it can be inferred that, as consumers assume sustainability attributes and the supply side interprets them through their marketing strategies, there will be a significant change in their presence and importance over the long-term. Figures 10-14 present the evolution of the positioning of sustainability attributes in real estate advertising in terms of their participation with regard to the total database. Given that real estate marketing strategies are generally interpreted based on cycles of contraction and expansion in the industry $[78,79]$, each graphic is accompanied by the annual variation in the indicator known as INACOR (Index of Regional Construction Activity or Índice de Actividad de la Construcción Regional) from the Chilean Chamber of Construction [80], which corresponds to the Metropolitan Region of Santiago for the same period. 
This is done not to provide an explanatory argument based on this single variable, but to propose a discussion regarding the mechanism of attributes and their correlation with the developers' strategies.

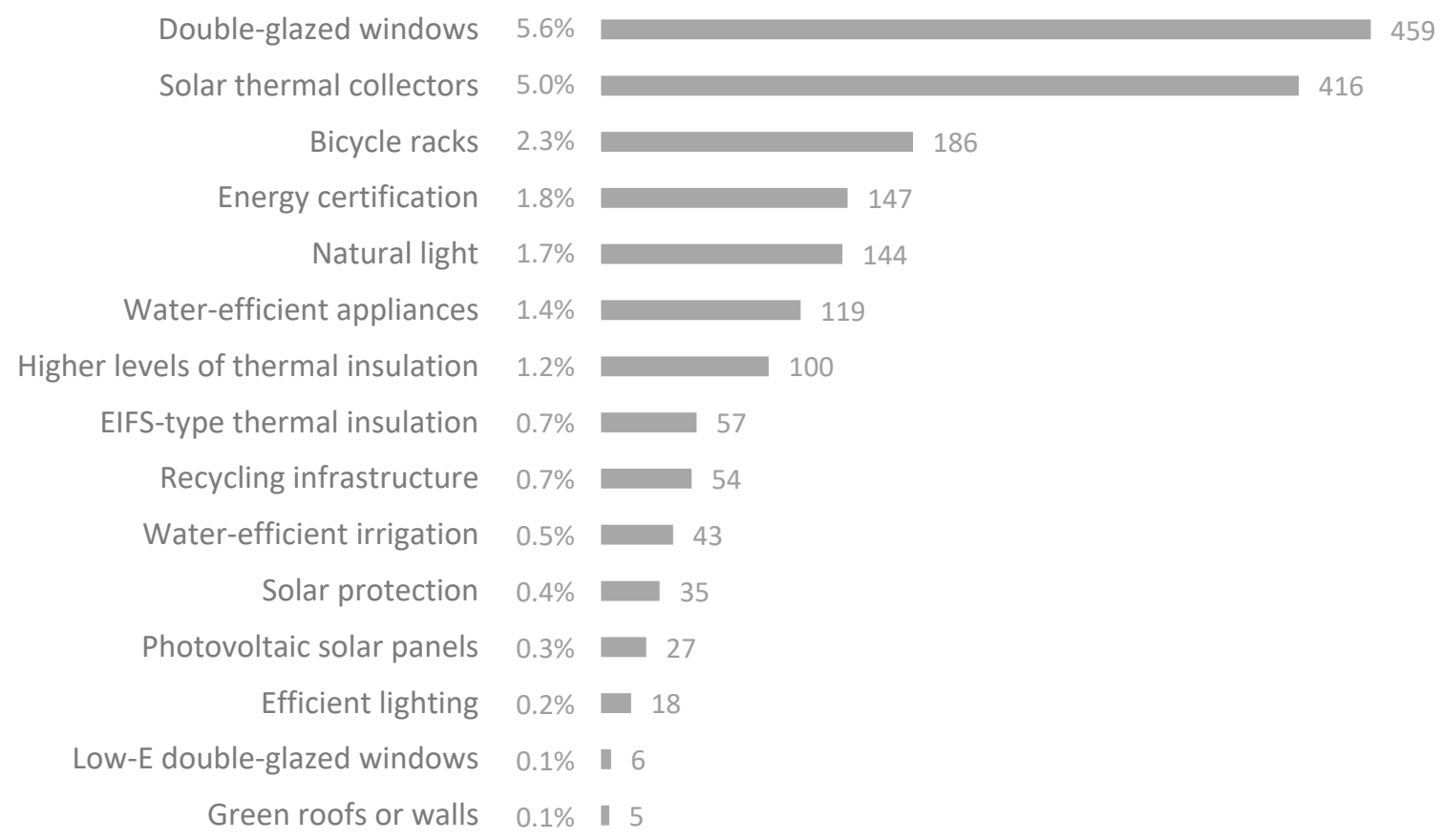

Figure 9. Frequency and percentage of the appearance of sustainability attributes in advertisements in the real estate promotion database for the period 2012-2017 $(N=8255)$. Note: the attribute "greater levels of thermal insulation" refers to those projects stating that they possess a greater level of insulation than required under current thermal regulations).

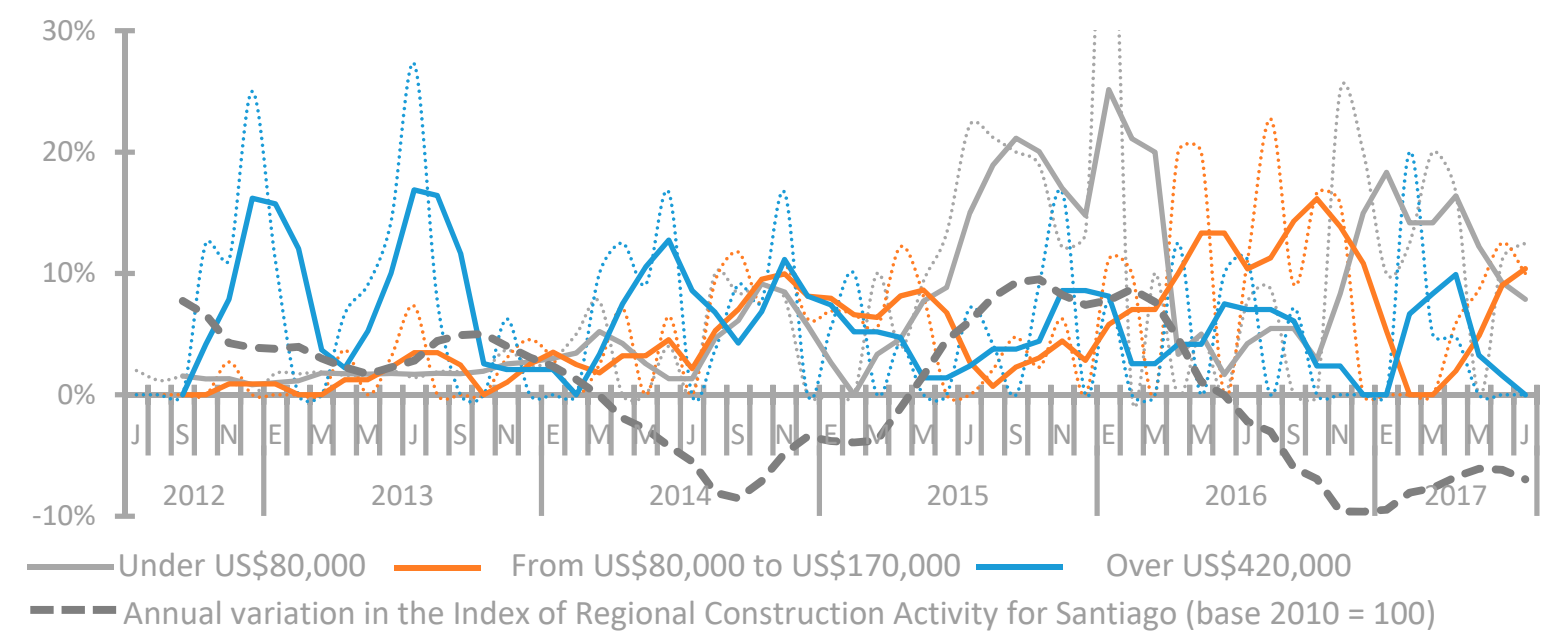

Figure 10. Presence of the attribute "double-glazed windows" (quarter) in real estate advertisements according to housing price range.

Given that in these graphs the positioning of the attributes offers segmented reading according to the three proposed price ranges, much higher percentages are observed in comparison to the total sample (Figure 9). An example of this is the attribute "double-glazed windows", which has a strong presence in the higher-priced segment at the beginning of the period and loses momentum over time, being surpassed in mid-2015 in the under US\$80,000 segment and in the third quarter of 2016 in the mid-priced segment (Figure 10). This can be explained by the fact that, in the higher price ranges, this type of attribute begins to be part of the expected construction standards and, hence, its differentiation 
capacity; as a result, interest in communicating it diminishes. However, the mass adoption of the attribute can favor lower-priced homes, which become capable of assuming the associated costs, even considering a utility with much less room to maneuver by developers.

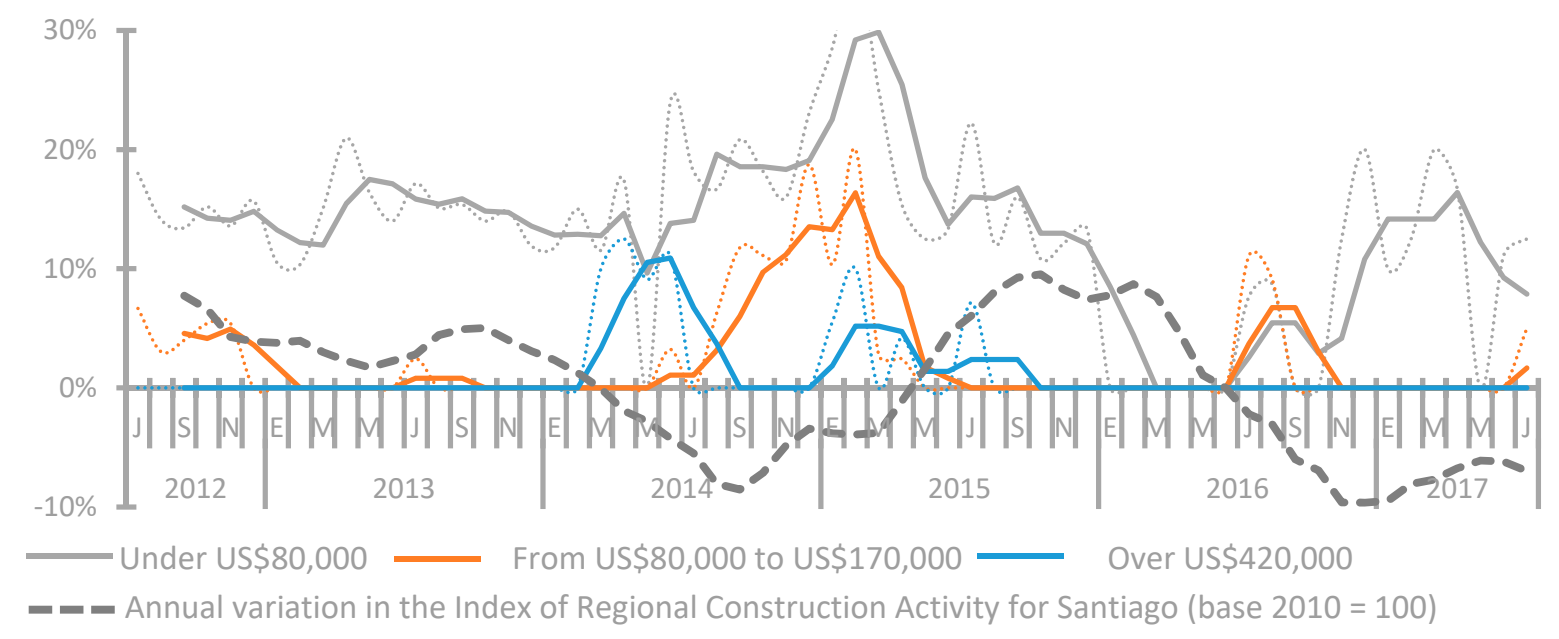

Figure 11. Presence of the attribute "thermal solar collectors" (quarter) in real estate advertisements according to housing price range.

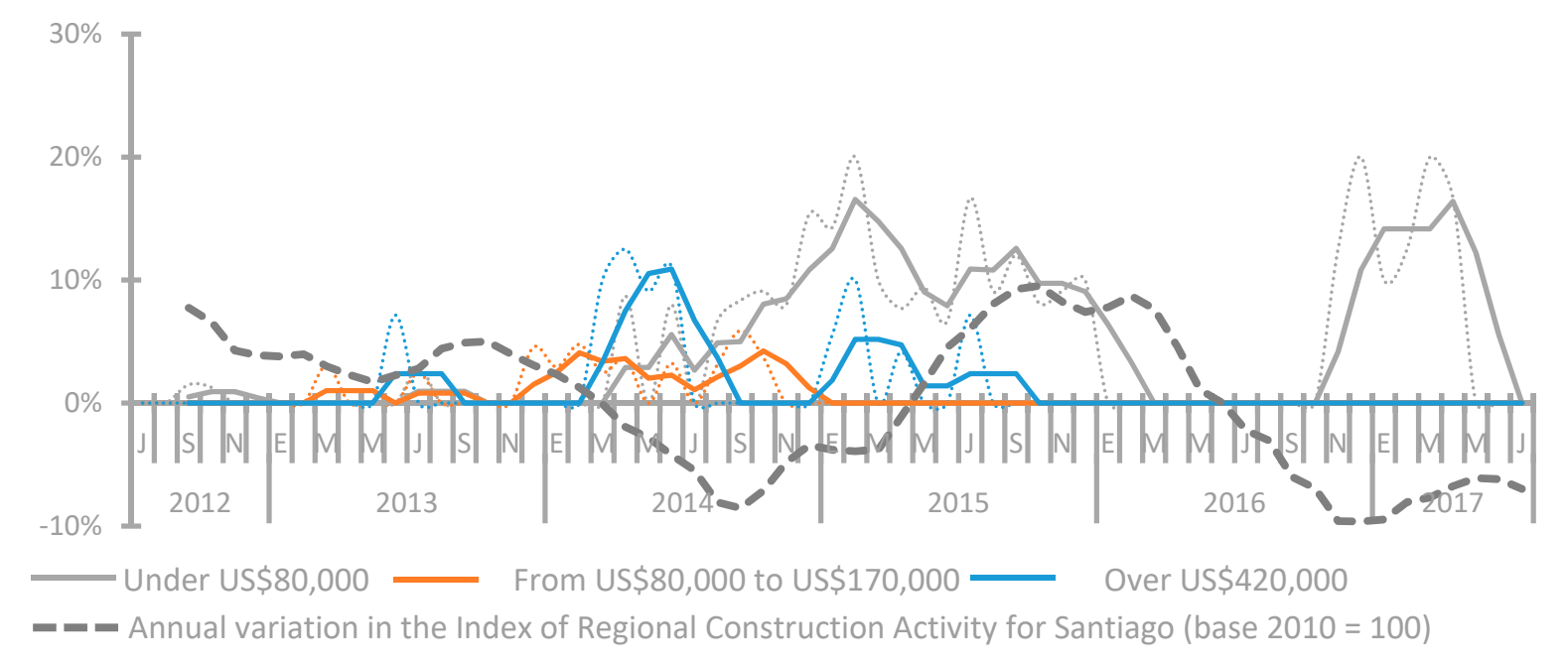

Figure 12. Presence of the attribute "water-efficient appliances" (quarter) in real estate advertisements according to housing price range.

Meanwhile, the attribute "thermal solar collectors" shows a sustained presence, especially in the lower-priced segment (Figure 11), demonstrating the impact of Law 20365 [81], which corresponds to a tax exemption for these types of system. This law benefits the totality of the value of the thermal solar system, including their installation and mandatory minimum maintenance, for homes whose value does not exceed 2000 CLF (US\$80,000). The attribute "water-efficient appliances" also has a majority association with this lower price range, and it disappears in the price ranges of US\$80,000 to US\$170,000 and over US $\$ 420,000$ as of the third quarter of 2015 (Figure 12).

However, the attributes "EIFS-type thermal insulation" and "energy certification" appear almost exclusively in the upper range of housing prices (Figures 13 and 14, respectively), although the register is sporadic in the case of the former. In this sense, the results of the attribute "energy certification" - associated mainly with LEED certification and the energy labelling by the Ministry of Housing and Urban Planning - demonstrate a particular behavior, with a clearly registered boom 
between 2013 and 2015 in the high-priced segment. Meanwhile, with a clear decrease in this price range as of this date (at least in terms of real estate advertisements), it appears with greater intensity in the US\$80,000 to US\$170,000 segment, which could represent an opening for the incorporation of energy certification into more mass-scale housing products. However, given the small quantity of housing units involved, it is not possible to establish a clear projection with regard to the adoption of voluntary certification systems by the market.

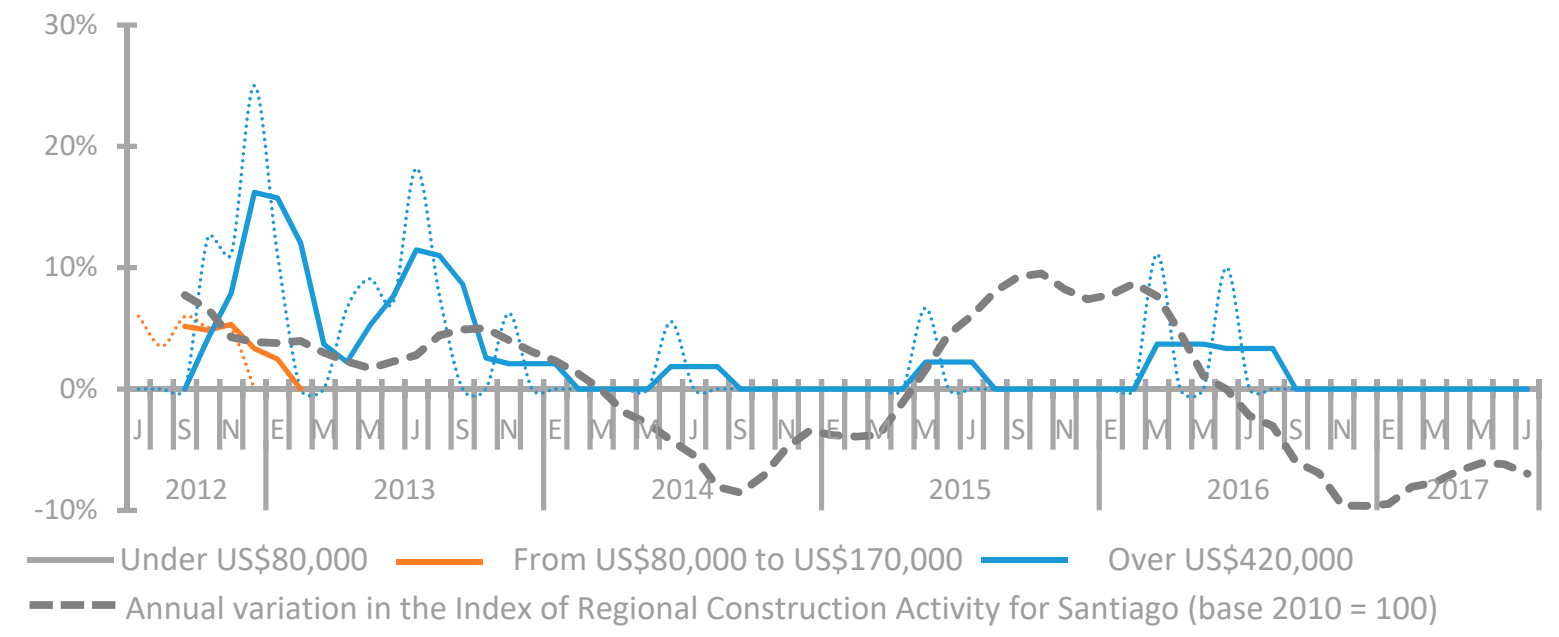

Figure 13. Presence of the attribute "EIFS-type thermal insulation" (quarter) in real estate advertisements according to housing price range.

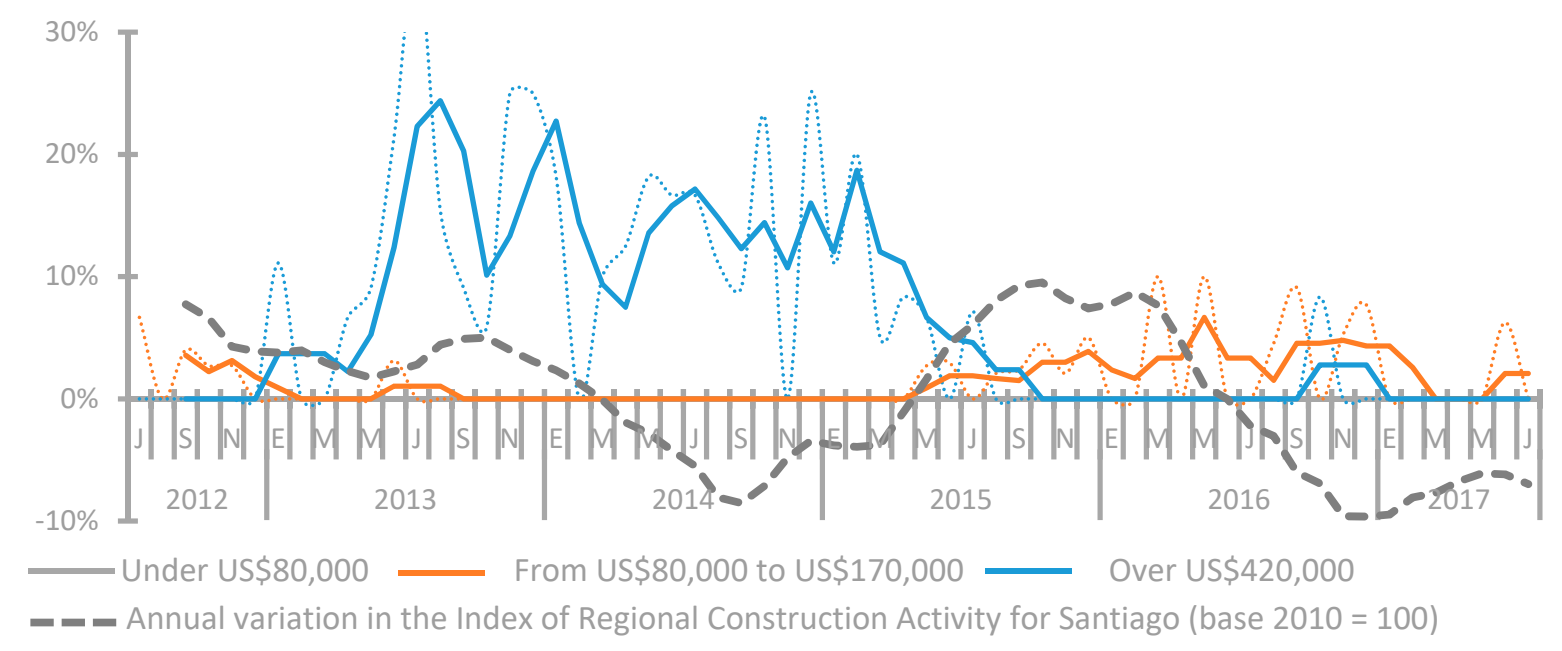

Figure 14. Presence of the attribute "energy certification" (quarter) in real estate advertisements according to housing price range.

If thus far the level of presence of the different attributes has been identified through a longitudinal analysis for the period 2012 to 2017, it is pertinent to examine the results obtained for the level of importance they demonstrate, with the understanding that the cross-comparison of the information with regard to both aspects can shed new light on the evolution of real estate promotion in terms of its approach to sustainable construction. As mentioned in the methodology section, it was determined whether the message associated with each attribute appeared with low, medium or high importance through a content analysis of the advertisements.

In this way, it is possible to observe differences between the different types of attributes in terms of their evolution over time. On one hand, the results for the attributes "double-glazed windows", "thermal solar collectors", "water-efficient appliances" and "EIFS-type thermal insulation" 
(Figures 15-18, respectively) demonstrate that while they were initially associated with medium and high levels of importance, as of September 2015-an inflection point in construction activity after a sharp contraction in the industry-they began to be relegated to the category of low importance within real estate promotion. It is not by chance, then, that the advertisements presented as examples of their positioning appear more frequently towards the beginning of the period of study (Figures 5-8). Although some of these offerings present signs of recovery in their level of importance in mid-2016-after experiencing a complete cycle of growth and shrinkage in the industry-they demonstrate high fragility in their positioning as sales arguments, being highly variable. In this sense, the exception appears to be the attribute "energy certification" (Figure 19), which demonstrates the greatest long-term stability as a relevant element in real estate promotion. This situation reveals the great potential of certification models to lead communication from the supply side in terms of energy efficiency and sustainability, to the detriment of attributes presented in terms of a single characteristic.

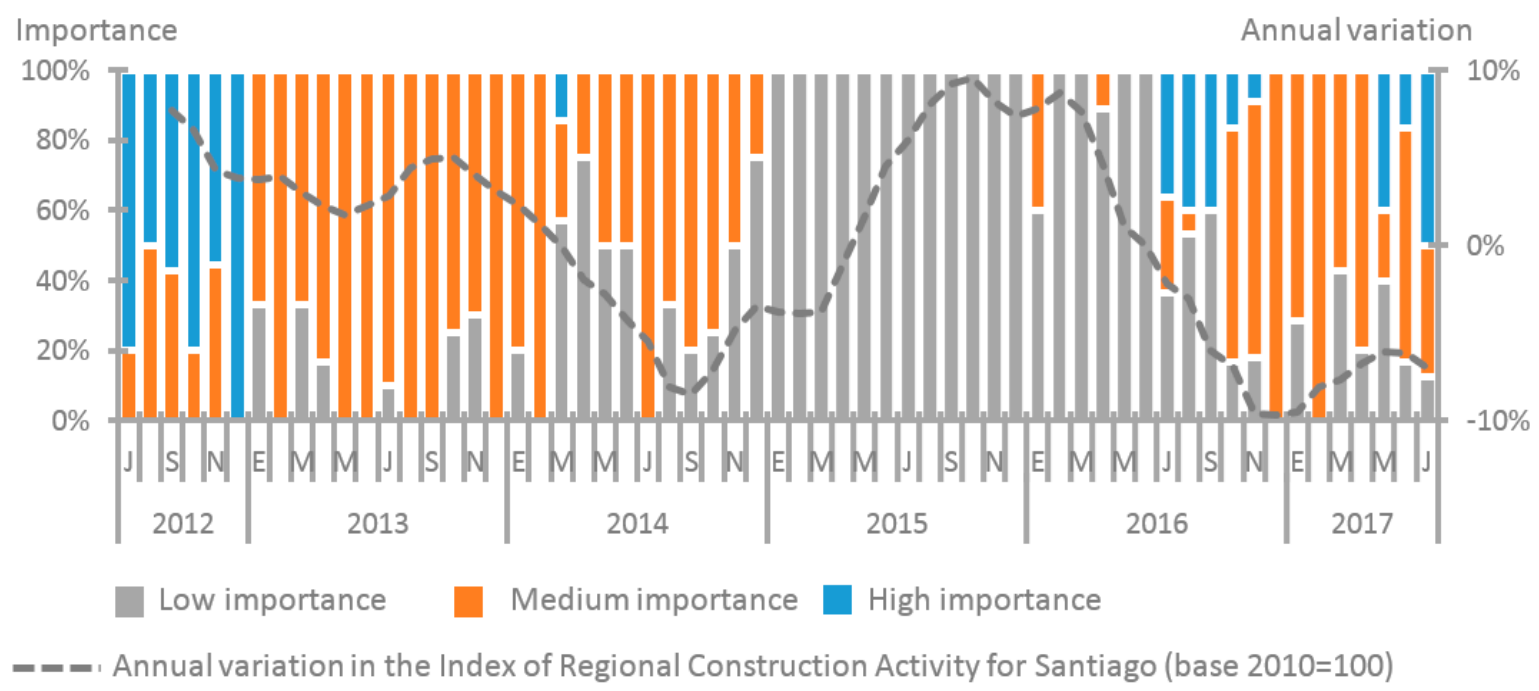

Figure 15. Level of importance of the attribute "double-glazed windows" in advertisements in which it appears, by month.

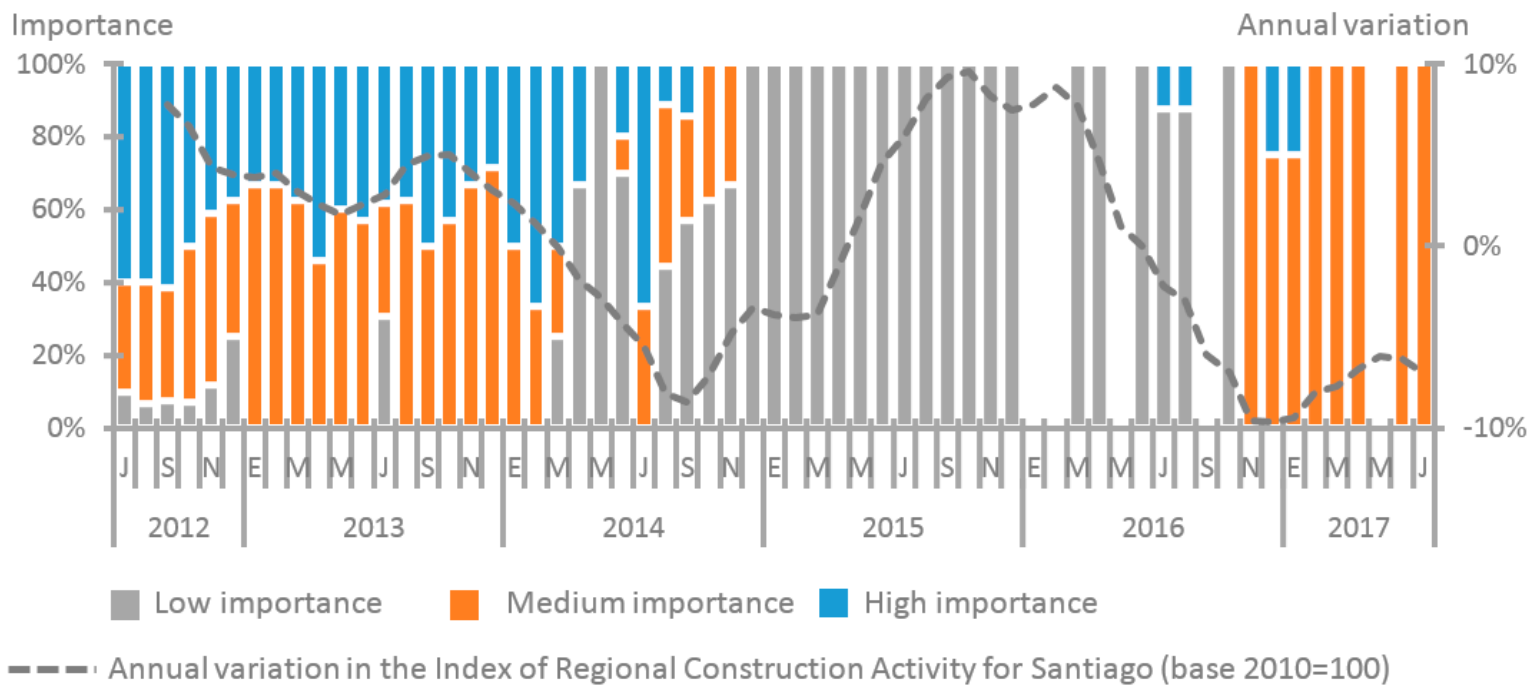

Figure 16. Level of importance of the attribute "solar thermal collectors" in advertisements in which it appears, by month. 


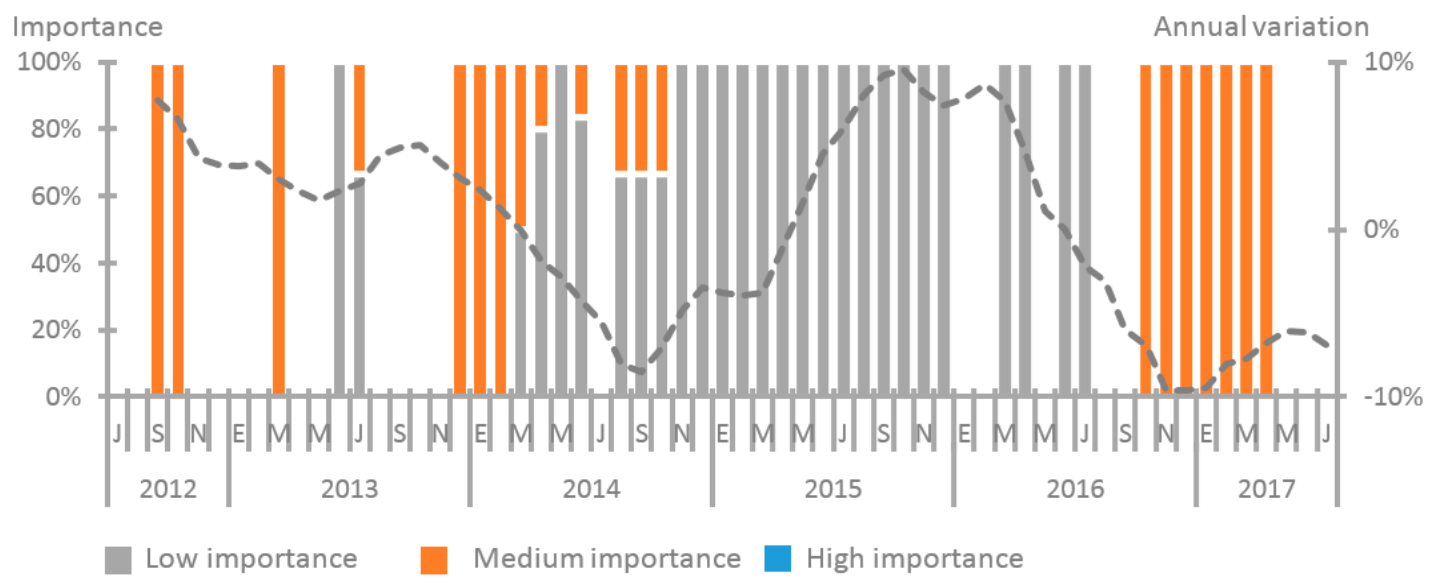

- Annual variation in the Index of Regional Construction Activity for Santiago (base $2010=100$ )

Figure 17. Level of importance of the attribute "water-efficient appliances" in advertisements in which it appears, by month.

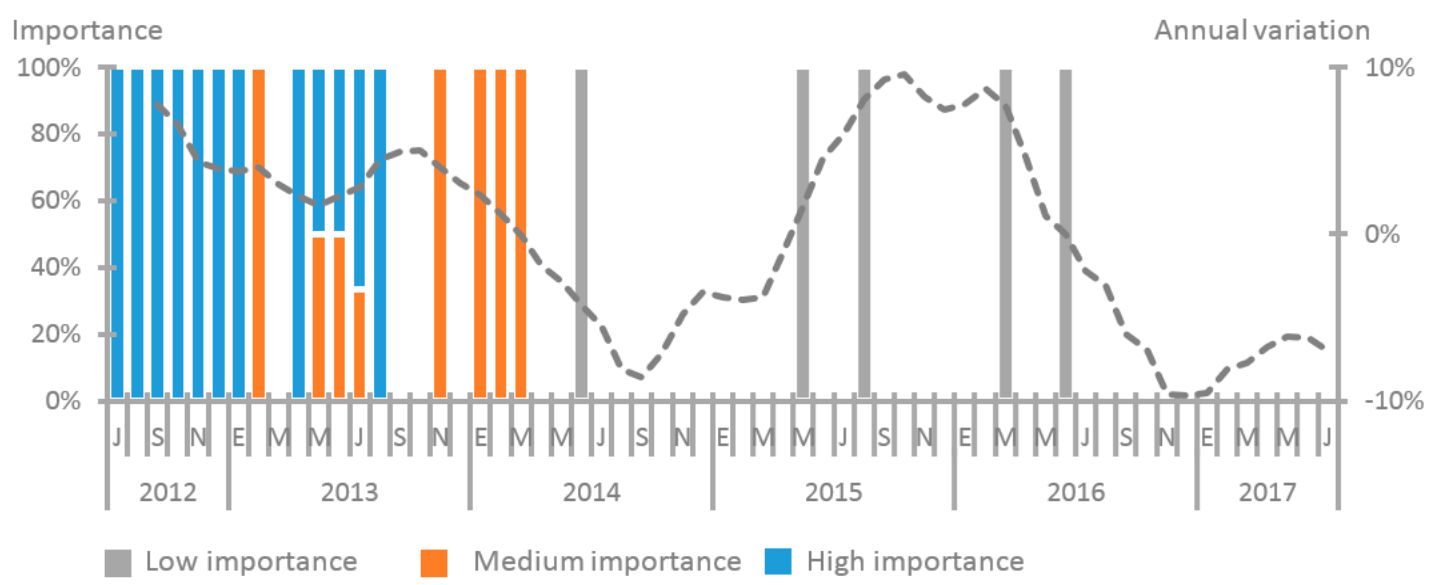

- - Annual variation in the Index of Regional Construction Activity for Santiago (base $2010=100$ )

Figure 18. Level of importance of the attribute "EIFS-type thermal insulation" in advertisements in which it appears, by month.

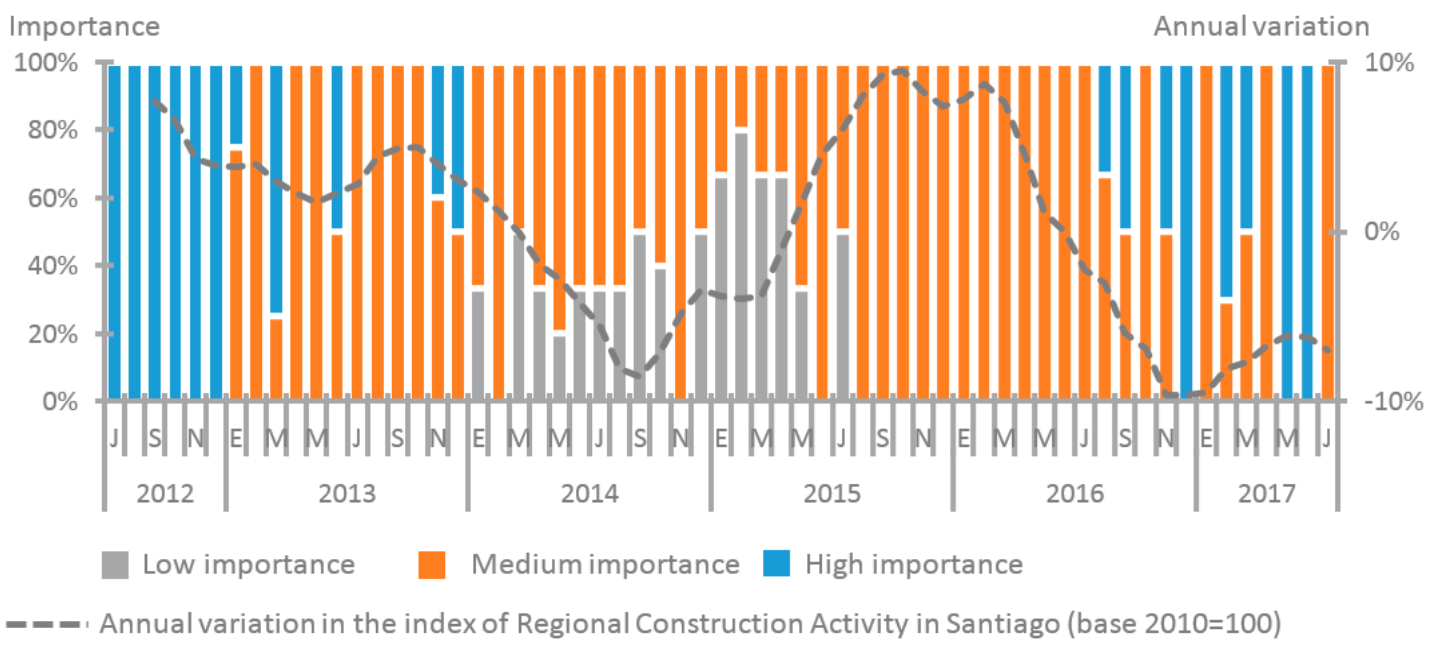

Figure 19. Level of importance of the attribute "energy certification" in advertisements in which it appears, by month. 


\section{Conclusions}

The logic of the allocation and promotion of the attributes associated with real estate products is born out of the conception of how they add value and enhance the attractiveness of such products and, thus, increase demand. To do this, the industry takes a reading of how consumers value each of these attributes. This valuation differs in each one of the territorial sub-markets, and, in a city as residentially segregated as Santiago, it also involves housing price segregation. In this sense, developers interpret these attributes in different ways, promoting them based on the segment in which they are competing. Meanwhile, consumers generate a sort of zero-sum balance between their purchasing ability and debt (expressed in the final price of housing) and the valuation of each one of the real estate attributes. This responds to how the consumer understands, recodifies and values the publicity effort.

In an initial reading, the positioning of the majority of sustainability attributes is more evident among consumers with higher acquisitive power (defined as consolidated attributes based on the cross-sectional analysis), as opposed to those in the lower-priced markets in which attributes are highlighted that do not significantly affect the margin of utility of the developers (such as bicycle racks). However, this situation is dynamic over time, as the emerging attributes can become consolidated if demand identifies (or wagers on) the existence of a willingness among consumers to pay for them, as well as the uncertain attributes that can also come to be consolidated, if demand is incentivized with greater competitiveness in the supply or by better communication by developers. Conversely, new disincentives can be produced in the development of certain characteristics of the projects, and both emerging attributes and uncertain ones can move to the category of disposability.

In this sense, the longitudinal analysis has warned of the loss of relative importance of some sustainability attributes over time, especially those expressed at the individual level of elements (such as "double glazed windows" or "solar thermal collectors") whose prominence is evident until-due to regulations or massification in supply—-they end up being standardized and thus no longer have any effect on residential differentiation. In this sense, the attribute "energy certification" is practically the only one that could possess the potential to create a permanent proposal for the construction of value, especially based on its capacity to objectively communicate a building's energy performance, overcoming information asymmetries for consumers. The international experience-especially based on European energy certificates-suggests that these instruments are in fact capable of incentivizing the market to make progress towards the provision of real estate products with greater levels of energy efficiency, observed, for example, through the generation of market premiums associated with the best qualified homes. Following that line, as this article explores real estate projects as research subject, an econometric model based on transaction prices-which are still not available for the complete period 2012 to 2017-is proposed as future work. The aim of this second stage is to examine the revealed preferences of buyers with respect to energy certification in comparison to individual real estate attributes.

However, the presence of weak minimum standards for energy performance means that it is easy to access any type of improvement without it actually representing a significant contribution to energy efficiency, opening the door to the practice of greenwashing. In this sense, the improvement of mandatory minimum standards established under current thermal regulations could incentivize competitiveness within the market, generating better housing products not only in terms of quality and after-sales but also in terms of the provision of energy-efficient construction solutions and energy-efficient technology. At the same time, the communications approach utilized in this article suggests the need for a review of energy certification policies, given that, as they are currently voluntary, they must compete equally with other attributes (in comparison, for example, with locational ones that tend to be very relevant in the middle-income segments). Finally, the results presented reveal how information asymmetry also operates in a segregated manner, with different levels of valuation regarding sustainability in different housing submarkets. Public policy should be more sensitive to these differences, especially when, for low-income sectors, there is a much narrower margin in the 
relationship between sales price and housing financing as a determinant of the maximum price to be paid for housing.

Acknowledgments: This research received funding from the National Commission for Scientific and Technological Research of Chile CONICYT through the FONDECYT Research Initiation Project No. 11130556 "Analysis and positioning of the attributes of energy efficiency and sustainability in the residential housing market of Santiago." We also received support from the Centre for Sustainable Urban Development (CEDEUS), CONICYT /FONDAP Project 15110020 . The real estate advertising database was built between June 2016 and July 2017 by the students of the Master in Sustainable Architecture and Energy [Magister en Arquitectura Sustentable y Energía] of the School of Architecture at the Pontificia Universidad Católica de Chile: José Caamaño, Christiane Delucchi, Mari Paz and Daniela Poblete.

Author Contributions: Felipe Encinas and Carlos Aguirre conceived and designed both methodological approaches; Carlos Aguirre and Felipe Encinas conducted the cross-validation of attributes in two microsectors, and the longitudinal analysis of attributes in real estate promotion, respectively; Carlos Marmolejo built the theoretical framework and contributed to the market analysis and interpretation of results; and Felipe Encinas wrote the paper. All authors read and approved this version.

Conflicts of Interest: The authors declare no conflict of interest.

\section{References}

1. Hough, D.E.; Kratz, C.G. Can "good" architecture meet the market test? J. Urban Econ. 1983, 14, 40-54. [CrossRef]

2. Vandell, K.D.; Lane, J.S. The economics of architecture and urban design: Some preliminary findings. Real Estate Econ. 1989, 17, 235-260. [CrossRef]

3. Plaut, S.; Uzulena, E. Architectural design and the value of housing in Riga, Latvia. Int. Real Estate Rev. 2006, 9, 112-131.

4. Macmillan, S. Added value of good design. Build. Res. Inf. 2006, 34, 257-271. [CrossRef]

5. The Royal Institute of British Architects (RIBA). Good Design -It All Adds Up; The Royal Institute of British Architects: London, UK, 2011.

6. Pulselli, R.M.; Simoncini, E.; Pulselli, F.M.; Bastianoni, S. Emergy analysis of building manufacturing, maintenance and use: Em-building indices to evaluate housing sustainability. Energy Build. 2007, 39, 620-628. [CrossRef]

7. Chartered Association of Building Engineers (CABE). The Value of Housing Design and Layout; Chartered Association of Building Engineers: London, UK, 2003.

8. Lancaster, K.J. A New Approach to Consumer Theory. J. Political Econ. 1966, 74, 132. [CrossRef]

9. Rosen, S. Hedonic Prices and Implicit Markets: Product Differentiation in Pure Competition. J. Political Econ. 1974, 82, 34-55. [CrossRef]

10. Jansen, S. Chapter 5. The Multi-attribute Utility Method. In The Measurement and Analysis of Housing Preference and Choice; Jansen, S., Coolen, H., Goetgeluk, R., Eds.; Springer: Dordrecht, The Netherlands, 2011; pp. 101-125, ISBN 978-90-481-8893-2. [CrossRef]

11. Marmolejo, C.; Echavarría, J.C.; Biere, R. El valor de la centralidad: Un análisis para la Barcelona Metropolitana. Archit. City Environ. 2016, 11, 95-112. [CrossRef]

12. Encinas, F; Tironi, M. Singularizando estilos de vida. Fabricación de imaginarios en condominios cerrados en Santiago. Rev. ARQ 2016, 56-67. [CrossRef]

13. Keeping, M. What about Demand? Do Investors Want "Sustainable Buildings"? RICS Research Foundation: London, UK, 2000.

14. Corporación de Desarrollo Tecnológico (CDT). Guía Desarrollo Sustentable de Proyectos Inmobiliarios; Corporación de Desarrollo Tecnológico, Cámara Chilena de la Construcción: Santiago, Chile, 2015.

15. Hwang, S.; Thill, J.-C. Influence of Job Accessibility on Housing Market Processes: Study of Spatial Stationarity in the Buffalo and Seattle Metropolitan Areas. In Geospatial Analysis and Modelling of Urban Structure and Dynamics; Jiang, B., Yao, X., Eds.; Springer: Dordrecht, The Netherlands, 2010; pp. 373-391.

16. Bourdieu, P. The Social Structures of the Economy, 1st ed.; Polity Press: Cambridge, UK, 2005.

17. Instituto Nacional de Estadísticas País y Regiones Por Áreas Urbana-Rural: Actualización Población 2002-2012 y Proyecciones 2013-2020. Available online: http://www.ine.cl/estadisticas/demograficas$\mathrm{y}$-vitales (accessed on 9 October 2017). 
18. CChC Mercado Inmobiliario-Oferta Nacional y Gran Santiago. Available online: http:/ / www.cchc.cl/centrode-informacion/indicadores/mercado-inmobiliario-oferta-nacional (accessed on 9 October 2017).

19. Hong, T. A close look at the China Design Standard for Energy Efficiency of Public Buildings. Energy Build. 2009, 41, 426-435. [CrossRef]

20. Mwasha, A.; Williams, R.G.; Iwaro, J. Modeling the performance of residential building envelope: The role of sustainable energy performance indicators. Energy Build. 2011, 43, 2108-2117. [CrossRef]

21. Pagliaro, F.; Cellucci, L.; Burattini, C.; Bisegna, F.; Gugliermetti, F.; de Lieto Vollaro, A.; Salata, F.; Golasi, I. A Methodological Comparison between Energy and Environmental Performance Evaluation. Sustainability 2015, 7, 10324-10342. [CrossRef]

22. Roulet, C.-A.; Flourentzou, F.; Labben, H.H.; Santamouris, M.; Koronaki, I.; Dascalaki, E.; Richalet, V. ORME: A multicriteria rating methodology for buildings. Build. Environ. 2002, 37, 579-586. [CrossRef]

23. Burattini, C.; Nardecchia, F.; Bisegna, F.; Cellucci, L.; Gugliermetti, F.; Vollaro, A.; Salata, F.; Golasi, I. Methodological Approach to the Energy Analysis of Unconstrained Historical Buildings. Sustainability 2015, 7, 10428-10444. [CrossRef]

24. Pérez-Lombard, L.; Ortiz, J.; González, R.; Maestre, I.R. A review of benchmarking, rating and labelling concepts within the framework of building energy certification schemes. Energy Build. 2009, 41, 272-278. [CrossRef]

25. Harvey, D. From Managerialism to Entrepreneurialism: The Transformation in Urban Governance in Late Capitalism. Geogr. Ann. Ser. B 1989, 71, 3-17. [CrossRef]

26. López-Morales, E.; Gasic Klett, I.; Meza Corvalán, D. Urbanismo proempresarial en Chile: Políticas y planificación de la producción residencial en el altura en el pericentro del Gran Santiago. Rev. INVI 2012, 27, 75-114. [CrossRef]

27. Ministry of Housing and Urbanism Planning (MINVU). Política Nacional de Desarrollo Urbano. Ciudades Sustentables y Calidad de Vida; Giménez, P., Ugarte, J.R., Eds.; Ministerio de Vivienda y Urbanismo/Ministry of Housing and Urban Planning: Santiago, Chile, 2014; ISBN 9789567674787.

28. Ministry of Housing and Urbanism Planning (MINVU). Ordenanza General de Urbanismo y Construcciones; Ministry of Housing and Urban Planning: Santiago, Chile, 2016.

29. Reus, G.; Czajkowski, J.D. Comparación entre las normas de desempeño térmico edilício de Argentina y Brasil. Ambient. Construído 2016, 16, 105-122.

30. Fossati, M.; Scalco, V.A.; Linczuk, V.C.C.; Lamberts, R. Building energy efficiency: An overview of the Brazilian residential labeling scheme. Renew. Sustain. Energy Rev. 2016, 65, 1216-1231. [CrossRef]

31. Lopes, A.d.C.P.; Oliveira Filho, D.; Altoe, L.; Correna Carlo, J.; Bastos Lima, B. Energy efficiency labeling program for buildings in Brazil compared to the United States' and Portugal's. Renew. Sustain. Energy Rev. 2016, 66, 207-219. [CrossRef]

32. Bustamante, W.; Rozas, Y.; Cepeda, R.; Encinas, F.; Martínez, P. Guía de Diseño Para la Eficiencia Energética en la Vivienda Social; Bustamante, W., Ed.; Pontificia Universidad Católica de Chile, Ministerio de Vivienda y Urbanismo, División Técnica de Estudio y Fomento Habitacional (DITEC) y Programa País de Eficiencia Energética: Santiago, Chile, 2009.

33. Collados, E.; Armijo, G. Predicting the impacts of an energy refurbishing programme in Chile: More than energy savings. In A Handbook of Sustainable Building Design and Engineering. An Integrated Approach to Energy, Health and Operational Performance of Buildings; Mumovic, D., Santamouris, M., Eds.; Earthscan Ltd.: London, UK, 2008; ISBN 9781844075966.

34. Celis, F.; García, R.; Trebilcock, M.; Escorcia, O.; Miotto, U.; Diaz, M. Análisis energético de las viviendas del centro-sur de Chile. Arquiteturarevista 2012, 8, 62-75. [CrossRef]

35. Caldera Sánchez, A. Building Blocks for a Better Functioning Housing Market in Chile; OECD Publishing: Paris, France, 2012.

36. Ministry of Housing and Urban Planning (MINVU). NTM 011/2 2014 Anteproyecto-Requisitos y Mecanismos de Acreditación Para Acondicionamiento Ambiental de las Edificaciones. Parte 2: Comportamiento Higrotémico; Ministry of Housing and Urban Planning: Santiago, Chile, 2014.

37. Ministry of Housing and Urban Planning (MINVU). Estándares de Construcción Sustentable Para Viviendas de Chile. Tomo II Energía; Ministry of Housing and Urban Planning: Santiago, Chile, 2016; ISBN 978-956-9432-53-8. 
38. Ministry of Energy. Agenda de Energía. Un Desafio País, Progreso Para Todos; Ministry of Energy: Santiago, Chile, 2014.

39. 2002/91/EC of the European Parliament and of the Council of 16 December 2002 on the energy performance of buildings 2003. Official Journal of the European Union Directive, 4 January 2003, pp. 65-71.

40. División Técnica de Estudio y Fomento Habitacional (DITEC). Sistema de Calificación Energética de Viviendas en Chile; Ministerio de Vivienda y Urbanismo: Santiago, Chile, 2015.

41. Ministerio de Vivienda y Urbanismo (MINVU). Informe Técnico Sistema de Calificación Energética de Viviendas. Available online: http://www.calificacionenergetica.cl/informe-tecnico/ (accessed on 24 October 2017).

42. Castro-Lacouture, D.; Sefair, J.A.; Flórez, L.; Medaglia, A.L. Optimization model for the selection of materials using a LEED-based green building rating system in Colombia. Build. Environ. 2009, 44, 1162-1170. [CrossRef]

43. Scofield, J.H. Efficacy of LEED-certification in reducing energy consumption and greenhouse gas emission for large New York City office buildings. Energy Build. 2013, 67, 517-524. [CrossRef]

44. Smith, A. An Inquiry into the Nature and Causes of the Wealth of Nations, 5th ed.; Cannan, E., Ed.; Methuen \& Co., Ltd.: London, UK, 1776.

45. Harvey, D. Social Justice and the City; Blackwell Publishers: Oxford, UK, 1973.

46. Schmitz, A.; Brett, D.L. Real Estate Markey Analysis; The Urban Land Institute: Washington, DC, USA, 2001.

47. Ferrando Corell, J.V.; Ferrando Ortiz, J.; Ferrando Ortiz, A. El inmueble: Significantes de su valor. ACE Archit. City Environ. 2017, 12, 123-142. [CrossRef]

48. Encinas, F.; Marmolejo, C.; Aguirre, C. El impacto de los proyectos inmobiliarios y sus atributos de sustentabilidad sobre el valor del suelo: ¿causa o consecuencia? Dos estudios de casos para Santiago de Chile. Rev. Hábitat Sustentable 2016, 6, 70-79.

49. Harvey, D. Rebel Cities: From the Right to the City to the Urban Revolution; Verso: London, UK, 2012.

50. Popescu, D.; Bienert, S.; Schützenhofer, C.; Boazu, R. Impact of energy efficiency measures on the economic value of buildings. Appl. Energy 2012, 89, 454-463. [CrossRef]

51. Del Giudice, V.; De Paola, P.; Manganelli, B.; Forte, F. The Monetary Valuation of Environmental Externalities through the Analysis of Real Estate Prices. Sustainability 2017, 9, 229. [CrossRef]

52. Dinan, T.M.; Miranowsky, J.A. Estimating the implicit price of energy efficiency improvements in the residential housing market: A hedonic approach. J. Build. Econ. 1989, 25, 52-67. [CrossRef]

53. Kahn, M.E.; Kok, N. The capitalization of green labels in the California housing market. Reg. Sci. Urban Econ. 2013, 47, 25-34. [CrossRef]

54. Bruegge, C.; Carrión-Flores, C.; Pope, J.C. Does the housing market value energy efficient homes? Evidence from the energy star program. Reg. Sci. Urban Econ. 2015. [CrossRef]

55. Fuerst, F.; McAllister, P. Green Noise or Green Value? Measuring the Effects of Environmental Certification on Office Values. Real Estate Econ. 2011, 39, 45-69. [CrossRef]

56. Reichardt, A.; Fuerst, F.; Rottke, N.B.; Zietz, J. Sustainable Building Certification and the Rent Premium: A Panel Data Approach. J. Real Estate Res. 2012, 34, 99-126.

57. De Ayala, A.; Galarraga, I.; Spadaro, J.V. The price of energy efficiency in the Spanish housing market. Energy Policy 2016, 94, 16-24. [CrossRef]

58. Fuerst, F.; McAllister, P.M.; Nanda, A.; Wyatt, P. Is Energy Efficiency Priced in the Housing Market? Some Evidence from the United Kingdom. SSRN Electron. J. 2013, 1-34. [CrossRef]

59. Fuerst, F.; McAllister, P.; Nanda, A.; Wyatt, P. Final Project Report: An Investigation of the Effect of EPC Ratings on House Prices; Department of Energy \& Climate Change: London, UK, 2013.

60. Gelegenis, J.; Diakoulaki, D.; Lampropoulou, H.; Giannakidis, G.; Samarakou, M.; Plytas, N. Perspectives of energy efficient technologies penetration in the Greek domestic sector, through the analysis of energy performance certificates. Energy Policy 2014, 67, 56-67. [CrossRef]

61. Marmolejo, C. La incidencia de la calificación energética sobre los valores residenciales: Un análisis para el mercado plurifamiliar en Barcelona. Inf. Constr. 2016, 68, 156. [CrossRef]

62. Fuerst, F.; McAllister, P.; Nanda, A.; Wyatt, P. Energy performance ratings and house prices in Wales: An empirical study. Energy Policy 2016, 92, 20-33. [CrossRef]

63. Murphy, L. The influence of the energy performance certificate: The Dutch case. Energy Policy 2014, 67, 664-672. [CrossRef] 
64. Fuerst, F.; McAllister, P.; Nanda, A.; Wyatt, P. Does energy efficiency matter to home-buyers? An investigation of EPC ratings and transaction prices in England. Energy Econ. 2015, 48, 145-156. [CrossRef]

65. Fuerst, F.; Shimizu, C. Green Luxury Gods? The Economics of Eco-Labels in the Japanese Housing Market. J. Jpn. Int. Econ. 2016. [CrossRef]

66. Bio Intelligence Service; Lyons, R. IEEP Energy Performance Certificates in Buildings and Their Impact on Transaction Prices and Rents in Selected EU Countries; Bio Intelligence Service: Paris, France, 2013.

67. Bond, S.A.; Devine, A. Certification Matters: Is Green Talk Cheap Talk? J. Real Estate Financ. Econ. 2016, 52, 117-140. [CrossRef]

68. De Ruggiero, M.; Forestiero, G.; Manganelli, B.; Salvo, F. Buildings Energy Performance in a Market Comparison Approach. Buildings 2017, 7, 16. [CrossRef]

69. Hårsman, B.; Daghbashyan, Z.; Chaudhary, P. On the quality and impact of residential energy performance certificates. Energy Build. 2016, 133, 711-723. [CrossRef]

70. Freybote, J.; Sun, H.; Yang, X. The Impact of LEED Neighborhood Certification on Condo Prices. Real Estate Econ. 2015, 43, 586-608. [CrossRef]

71. Fernández, G.; Salcedo, R.; Torres, A. De la publicidad inmobiliaria a la vivencia cotidiana: Aspectos que permiten entender la evolución de las expectativas residenciales. In Barrios Cerrados en Santiago de Chile: Entre la Exclusión y la Integración Residencial; Cáceres, G., Sabatini, F., Eds.; Pontificia Universidad Católica de Chile, Instituto de Geografía: Santiago, Chile; Lincoln Institute of Land Policy: Cambridge, MA, USA, 2004; pp. 113-145.

72. Thyroff, A.E.; Kilbourne, W.E. Understanding pro-environmental intentions through growth, competitiveness, and concern. Australas. Mark. J. 2017, 25, 97-105. [CrossRef]

73. Kumar, P.; Polonsky, M.J. An analysis of the green consumer domain within sustainability research: 1975 to 2014. Australas. Mark. J. 2017, 25, 85-96. [CrossRef]

74. Dangelico, R.M.; Vocalelli, D. "Green Marketing": An analysis of definitions, strategy steps, and tools through a systematic review of the literature. J. Clean. Prod. 2017, 165, 1263-1279. [CrossRef]

75. Holtermans, R.; Kok, N. On the Value of Environmental Certification in the Commercial Real Estate Market. Real Estate Econ. 2017. [CrossRef]

76. División Técnica de Estudio y Fomento Habitacional (DITEC). Manual de Marca Calificación Energética de Viviendas Para Inmobiliarias y Evaluadores; Ministerio de Vivienda y Urbanismo: Santiago, Chile, 2013.

77. Ruiz-Tagle, J.; López, E. El estudio de la segregación residencial en Santiago de Chile: Revisión crítica de algunos problemas metodológicos y conceptuales. Revista Latinoamericana de Estudios Urban Regionales EURE 2014, 40, 25-48. [CrossRef]

78. Kauškale, L.; Geipele, I. Integrated Approach of Real Estate Market Analysis in Sustainable Development Context for Decision Making. Procedia Eng. 2017, 172, 505-512. [CrossRef]

79. Peiser, R. Real Estate Development. In International Encyclopedia of the Social E Behavioral Sciences; Elsevier: Amsterdam, The Netherlands, 2015; pp. 12-19, ISBN 9780080970875.

80. CChC Indicador: INACOR. Available online: http:/ /www.cchc.cl/centro-de-informacion/indicadores / inacor (accessed on 28 October 2017).

81. Establece Franquicia Tributaria Respecto de Sistemas Solares Térmicos. Ministerio de Hacienda Ley No. 20.365. 2016. Available online: https://www.leychile.cl/Navegar?idNorma=1005169 (accessed on 28 October 2017).

(c) 2018 by the authors. Licensee MDPI, Basel, Switzerland. This article is an open access article distributed under the terms and conditions of the Creative Commons Attribution (CC BY) license (http:/ / creativecommons.org/licenses/by/4.0/). 